\title{
Juízes eficientes, judiciário ineficiente no Brasil pós-1988
}

\author{
Luciano Da Ros ${ }^{\mathrm{I}}$ \\ Matthew MacLeod Taylor ${ }^{\text {II }}$ (D)
}

\section{Introdução}

Ao longo dos últimos 30 anos, o poder judiciário brasileiro foi refeito. As cortes abandonaram a timidez da era autoritária em decorrência da renovaçáo do quadro de magistrados e de uma nova Constituiçáo, que transformou seus fundamentos institucionais. ${ }^{1}$ Maior independência e mais recursos, legitimidade ampliada e a promessa democrática de igualdade perante a lei contribuíram para o vertiginoso aumento da demanda. Paralelamente, novas normas e prerrogativas ajudaram a colocar os tribunais no centro dos debates políticos.

Não obstante, a famosa declaração feita pelo então presidente Luiz Inácio Lula da Silva, em 2003, sobre "abrir a caixa-preta"2 do poder judiciário refletiu a percepção mais ampla do público na virada do século: os tribunais precisariam de uma reforma profunda para enfrentar as alegaçóes de opacidade institucional, inconsistência decisória e corrupção. Após mais de uma década de debate, uma grande reforma foi aprovada em 2004, a qual se somou a diversas mudanças incrementais realizadas nas décadas anteriores e seguintes. Em conjunto, essas reformas alteraram o sistema judicial brasileiro significativamente. Ainda assim, essa transformação permanece incompleta, e o poder judiciário segue incapaz de alcançar muitas aspiraçóes nele colocadas pela sociedade. De fato, ao tempo da escrita deste texto, novamente, há uma discussão sobre a necessidade de reformas visando à melhoria de seu desempenho.

Este artigo descreve as continuidades e mudanças desse novo poder judiciário construído ao longo das últimas décadas no Brasil. Analisamos a evolução institucional do sistema judicial, atentando-nos para o papel esperado das cortes em uma democracia. ${ }^{3}$ Tal papel pode ser examinado de acordo com sua facilidade de acesso, equidade de tratamento, eficiência e eficácia no

'Programa de Pós-Graduação em Políticas Públicas, Universidade Federal do Rio Grande do Sul - Porto Alegre (RS), Brasil. E-mail: luciano.daros@ufrgs.br

IISchool of International Service, American University - Washington, D.C., Estados Unidos. E-mail: mtaylor@american.edu Recebido em: 20/01/2019. Aprovado em: 17/04/2019.

\footnotetext{
${ }^{1}$ A maioria dos magistrados atualmente em serviço ingressou no judiciário após o regime militar. Menos de $15 \%$ dos juízes em serviço em 2018 foram empossados antes de 1990 (CNJ, 2018b).

${ }^{2}$ Disponível em: <http://www.jota.info/uma-decada-depois-da-caixa-preta>. Acesso em: 25 jan. 2015.

${ }^{3} \mathrm{O}$ objetivo de um judiciário democrático não é necessariamente usar procedimentos democráticos no sistema judicial, mas assegurar que o poder judiciário contribua para a democracia, garantindo o Estado de direito por meio de decisóes eficazes e rápidas, baseadas em igualdade de acesso e tratamento.
} 
cumprimento de sua missão institucional: a resoluçáo pacífica de conflitos por meio da interpretação obrigatória da legislação ${ }^{4}$. Em vista disso, destacamos os dois últimos aspectos e demonstramos a existência de um aparente descompasso entre magistrados de alta produtividade decisória e um poder judiciário de baixa resolutividade no Brasil, isto é, com reduzida capacidade de resolução definitiva de conflitos em tempo hábil, um ponto ao qual retomaremos pormenorizadamente adiante.

Dada a magnitude do tema, não buscamos ser exaustivos a seu respeito. Em vez disso, propomos uma análise descritiva ampla e de longo prazo sobre esses processos, os quais, por vezes, escapam aos estudos mais especializados que subsidiam o debate. Coerentes com esses objetivos, destacamos mudanças institucionais ocorridas tanto de forma abrupta e preponderantemente exógena, como alteraçôes incrementais, e sobretudo endógenas às instituiçóes do sistema de justiça (Mahoney; Thelen, 2009).

$\mathrm{O}$ artigo está organizado da seguinte forma. Inicia-se com uma breve revisão de literatura, que discute as diferentes perspectivas teóricas no estudo do poder judiciário. A segunda seçáo descreve a estrutura do sistema judicial brasileiro, esclarecendo os dilemas que vêm motivando as reformas desde a década de 1980 , e a terceira seção resume os esforços de reforma. Já a quarta seçâo analisa os efeitos do judiciário sobre quatro áreas fundamentais - economia, políticas públicas, corrupção e legitimidade democrática. A seção final examina o estado atual dos tribunais e faz discussôes recentes sobre as novas reformas.

\section{Perspectivas teóricas no estudo do poder judiciário}

Tradicionalmente, duas perspectivas projetam-se sobre o estudo de órgãos judiciais. A primeira examina o impacto da atuação das instituiçôes do sistema de justiça sobre diferentes fenômenos, como a dinâmica política e a implementação de políticas públicas (Canon; Johnson, 1999; Gauri; Brinks, 2009). Em síntese, trata-se de uma abordagem que analisa a atuação de juízes, advogados e demais operadores do direito preponderantemente como uma variável independente. A segunda perspectiva inverte essa polaridade. Ela busca analisar as instituiçôes judiciais e seus agentes como responsáveis pela prestação de uma política pública própria que, como tal, pode ser examinada pela ótica dos seus processos de formulação e implementação. Pesquisas que envolvem a reforma e o funcionamento dos órgãos judiciais ilustram esse universo (Hammergren, 2007; Cohen, 2002).

Ao invés de tratar essas duas pesrpectivas de maneira apartada, nossa sugestão é que elas devam ser analisadas conjuntamente, de modo a permitir uma avaliação mais abrangente do poder judiciário em diferentes contextos. Isto é, tanto as várias formas de funcionamento dos tribunais produzem impactos distintos sobre outras políticas públicas como esses diferentes impactos frequentemente ensejam discussóes pertinentes a reformas judiciais. Esse entendimento deriva de desenvolvimentos recentes da literatura que sugerem que o impacto dos órgãos judiciais é fruto de um processo inter-relacionado de pelo menos três outros fenôme-

4 Para tanto, seguimos as diretrizes do World Justice Project, disponíveis em: <http://worldjusticeproject.org/what-rule-law>. Acesso em: 25 jan. 2015. 
nos: o desenvolvimento das instituiçóes judiciais, o seu acionamento e o comportamento de seus integrantes (Ingram, 2015; Da Ros, 2017; Da Ros; Ingram, 2019a; 2019b; Hilbink; Ingram, 2019).

Dessa forma, em vez de cindirmos a literatura em apenas duas grandes partes, sugerimos que as abordagens teóricas disponíveis ao estudo de instituiçóes judiciais sejam ligeiramente mais diversificadas, permitindo desenvolvimentos teóricos em ao menos quatro frentes:

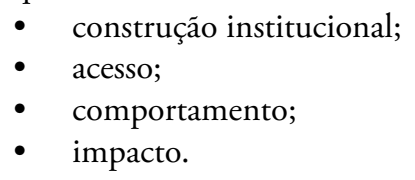

Revisamos brevemente essas quatro vertentes teóricas na sequência, de forma a subsidir nossa discussão sobre o funcionamento do poder judiciário ao longo das últimas três décadas no Brasil.

Em primeiro lugar, o debate sobre construção institucional engloba tanto a descrição dos diferentes desenhos institucionais do poder judiciário como teorias que dizem respeito às causas de eventuais reformas judiciais. Além de discutir a extensão das atribuiçóes formais e as formas de seleção e retenção dos integrantes dos tribunais, parte importante dessa literatura dedica-se a compreender sob quais condiçôes elites políticas decidem alterar os poderes das cortes, ora ampliando-os, ora limitando-os. Por um lado, a literatura sugere que elites políticas outrora hegemônicas fortaleceriam o poder judiciário de modo a se proteger ante sua eventual derrocada, sobretudo sob as alcunhas de insurance thesis e hegemonic preservation thesis (Ginsburg, 2003; Hirschl, 2004). Por outro, abundam trabalhos sobre court-curbing, por meio dos quais cortes se tornam alvo de diferentes tipos de ataques por parte de elites políticas ao obstaculizar a implementação de políticas públicas de seus interesses (Helmke, 2017; Pérez-Liñan; Castagnola, 2016). Embora sejam crescentes, parecem receber menor atenção estudos sobre reformas institucionais endógenas e baseadas em elementos ideacionais - em vez de necessariamente materiais. Não apenas esses estudos aparentam ser bastante consequentes para a atuaçáo do poder judiciário em geral, como também parecem ser especialmente importantes no contexto brasileiro (Nunes, 2010; Da Ros, 2014; Ingram, 2016).

Em segundo lugar, há a literatura no que tange ao acesso. Ele é uma extensão do item anterior: uma vez definidas as regras de funcionamento do poder judiciário, quem pode acioná-lo e com qual frequência o faz? Por um lado, essa discussão envolve compreender a amplitude de acesso às cortes decorrente dos diferentes modelos de judicial review adotados (concreto $v$ s. abstrato, difuso vs. concentrado, a priori vs. a posteriori etc.), incluindo combinaçōes entre eles (e.g., Navia; Ríos-Figueroa, 2005). Por outro, isso envolve apreender o uso desses mecanismos por diferentes atores políticos e sociais e as oportunidades legais para a litigância estratégica deles decorrentes (Dotan; Hofnung, 2005; Wilson; Cordero, 2006). Com efeito, os próprios debates sobre a judicialização da política - entendida como a expansão do escopo de conflitos políticos outrora resolvidos fora do poder judiciário em sua direção - e a mobilização do direito podem ser vistos como parte dessa literatura (Kapiszewski; Taylor, 2008).

Em terceiro lugar, há a discussão sobre comportamento. Novamente, esse debate é uma extensão dos dois anteriores: uma vez definidas as regras de funcionamento e acionados os tribunais, como os seus integrantes — os magistrados — decidem 
os casos que chegam a eles? A literatura indica uma combinação de diferentes fatores que afetam a maneira como os magistrados realizam seus julgamentos. Em geral, nesses fatores se incluem os seus atributos individuais (ideologias, lealdades político-partidárias, trajetórias profissionais, filiação a escolas de pensamento jurídico, níveis de aderência às missóes institucionais etc.), o processo de agregação de preferências na tomada de decisóes em órgãos colegiados (regras internas de funcionamento das cortes, controle da agenda decisória, expectativas dos pares etc.) e o relacionamento dos juízes com outros atores (incluindo tanto assessores como advogados, mas especialmente eventuais pressóes externas oriundas dos demais poderes do Estado e da própria opinião pública) (Cohen, 2002; Kapiszewski, 2011; Clark, 2012; Epstein; Landes; Posner, 2013). Em síntese, o comportamento judicial pode ser entendido como uma função do que os magistrados preferem fazer, moderado pelo que eles acreditam que devem fazer, constrangido pelo que eles acreditam ser viável fazer (Gibson, 1983). ${ }^{5}$

Finalmente, há a literatura no tocante ao impacto da atuaçáo dos tribunais. Mais uma vez, esse debate é a continuação dos anteriores: uma vez decidida a arquitetura institucional do judiciário, acionadas as cortes e julgados os casos, quais são as consequências de todos esses processos? Tal como as anteriores, o escopo dessa literatura é muito amplo. Ela abarca, por um lado, os efeitos mais gerais do judiciário sobre a sociedade, incluindo o seu impacto orçamentário, a extensão e o uso de seus poderes, a frequência e a saliência dos temas decididos etc. (Ingram, 2016; Hirschl, 2008). Paralelamente, o debate aborda os efeitos de decisóes judiciais que envolvem políticas públicas específicas, incluindo áreas tão diversas como saúde pública e encarceramento, entre diversas outras (Horowitz, 1977; Epp, 1998; Feeley; Rubin, 2000). Por fim, essa literatura examina ainda os diferentes níveis de compliance dos atores políticos na implementação de decisões judiciais, examinando sob quais condiçôes os posicionamentos do poder judiciário acarretam mais efeitos sobre as políticas públicas (Rosenberg, 1991; Hall, 2011; Kapiszewski; Taylor, 2013).

Como toda classificação de literatura, ela também apresenta alguma artificialidade. Com efeito, diversas pesquisas não podem ser enquadradas perfeitamente em uma das áreas indicadas, pois as analisam de modo transversal. Em parte, é isso que realizamos neste artigo. Isto posto, apresentamos em seguida quais vêm sendo algumas das principais características do funcionamento do judiciário brasileiro desde 1988 — incluindo os seus atributos institucionais mais gerais, as formas e a intensidade de acesso, o comportamento de seus integrantes e o impacto - a fim de subsidiar a discussão sobre suas reformas ao longo do tempo.

\section{O poder judiciário brasileiro em síntese}

A organização institucional do sistema judicial brasileiro fornece algumas pistas para as questóes que os reformistas vêm tentando enfrentar desde o retorno à democracia. Em síntese, o sistema é vasto, complexo

5 Uma vertente menos explorada dessa literatura são os papéis off-the-bench exercidos pelos magistrados, incluindo sua participação em processos de treinamento, participação em associações profissionais, lobby, discursos e palestras proferidas, entrevistas concedidas, entre outros (Ingram, 2016). 
e muito respeitado como árbitro de diversos tipos de conflito, em parte por conta da sua significativa independência. Todavia, o seu desempenho tem sido insatisfatório sob vários aspectos, incluindo, por exemplo, a resolução definitiva de litígios em tempo hábil e o tratamento igual perante a lei.

O poder judiciário brasileiro é organizado em cinco ramos distintos (estadual, federal, trabalhista, eleitoral e militar), concentrando os três primeiros mais de $90 \%$ dos casos, orçamento e recursos humanos. No ápice hierárquico está o Supremo Tribunal Federal (STF), com 11 ministros, que serve como corte final para questóes constitucionais e conflitos entre membros da federação. O STF possui tanto jurisdição original, em casos de revisão abstrata da legislação e questôes criminais envolvendo autoridades de alto escalão, quanto recursal, em casos com componente constitucional. Logo abaixo do STF estão os Tribunais Superiores, com atenção ao Superior Tribunal de Justiça (STJ), que é o tribunal de última instância em questôes não constitucionais.

Como um sistema federativo, cada um dos 26 estados brasileiros e o Distrito Federal têm seu próprio judiciário, com 8.644 varas e 27 Tribunais de Justiça (TJs), e estes também funcionam como cortes supremas em relação à legislação estadual. Um sistema judicial federal paralelo possui 773 varas e cinco Tribunais Regionais Federais (TRFs), cada um com jurisdiçáo sobre diversos esta- dos do país. Tanto o sistema estadual como o federal incluem milhares de juizados especiais para casos civis de pequeno valor e criminais de menor potencial ofensivo. Finalmente, o judiciário trabalhista, também mantido com recursos federais, abrange 1.572 varas e 24 Tribunais Regionais do Trabalho (TRTs), existentes em praticamente todos os estados do Brasil. No ápice desse ramo do poder judiciário está o Tribunal Superior do Trabalho (TST) (CNJ, 2018a, p. 19). ${ }^{6}$

A Constituição de 1988 transformou uma estrutura que tinha sido parcialmente defenestrada no regime militar em um impressionante juggernaut. Em 2017, os sistemas estadual, federal e trabalhista abarcavam ao todo mais de 18 mil magistrados, sendo 12.417 no judiciário estadual, 1.939 no federal e 3.658 no trabalhista (CNJ, 2018a, p. 34-42). ${ }^{7}$ Apesar de se valer amplamente das estruturas legais do passado, a Constituição de 1988 expandiu enormemente a autonomia e o acesso ao judiciário (Castro, 1997; Prillaman, 2000). A independência das cortes é assegurada atualmente por fortes garantias constitucionais, incluindo ampla autonomia administrativa, orçamentária e remuneratória.

O orçamento é generoso, totalizando $0,79 \%$ do produto interno bruto (PIB) para o poder judiciário estadual, $0,17 \%$ para o federal e $0,28 \%$ para o trabalhista, em quantia combinada de $\mathrm{R} \$ 81,7$ billhôes (CNJ, 2018a, p. 56-60). Se todos os níveis e ramos do judi-

6 Há também o Tribunal Superior Eleitoral (TSE) e o Superior Tribunal Militar, os quais são análogos ao STJ e TST, servindo como árbitros finais da interpretação não constitucional em suas respectivas áreas com possibilidade de recurso ao STF.

7 Isso equivale a 8,7 juízes por 100 mil habitantes (CNJ, 2018a), taxa que não é reduzida comparativamente, aproximando-se de países como Canadá $(8,0)$, Colômbia $(10,4)$, Itália $(10,6)$, França (10,7), Estados Unidos $(10,8)$, Espanha $(11,2)$ e Argentina $(11,4)$, sendo superior à de Venezuela $(6,8)$, Chile $(5,0)$, Reino Unido $(3,8) \mathrm{e}$ Japão $(2,8)$ e inferior à de Portugal $(19,2)$ e Alemanha $(24,7)$ (cf. CEJA, 2007; Ramseyer; Rasmusen, 2010; Banco Mundial, 2011; CEPEJ, 2016). 
ciário - estaduais, federais, trabalhistas, militares e eleitorais, bem como tribunais superiores - forem incluídos, o orçamento do poder judiciário brasileiro atingirá $\mathrm{R} \$ 90,8$ bilhōes, equivalentes a $1,38 \%$ do PIB, ou $\mathrm{R} \$ 437,47$ (US\$ 132,16) por habitante ao ano (CNJ, 2018a, p. 56-60). ${ }^{8}$ Com efeito, o Brasil pode possuir o orçamento judicial mais generoso por habitante de todos os sistemas federais do Hemisfério Ocidental, proporcionalmente à renda (Taylor, 2008; Da Ros, 2015). Os únicos países dos quais obtivemos dados que apontam despesa próxima àquela do poder judiciário brasileiro são Costa Rica (1,25\% do PIB), Argentina (1,05\%) e El Salvador (0,99\%). ${ }^{9}$ Os demais países nas Américas e na Europa apresentam despesas significativamente inferiores, mantendo-se todos abaixo de $0,6 \%$ do PIB (Gráfico 1). Mesmo a despesa per capita absoluta do judiciário brasileiro é superior à de todos os países europeus, com exceção da Suíça (€ 135) (CEPEJ, 2016, p. 35).

Do mesmo modo, magistrados recebem proporcionalmente mais do que seus colegas em outros países, e a escala remuneratória é comprimida, com vencimentos de juízes de instâncias inferiores, sendo próximos aos vencimentos dos ministros do STF. Juízes federais recém-empossados, por exemplo, recebem $81 \%$ dos vencimentos básicos dos ministros do STF. Com efeito, juízes federais em início de carreira recebem R $\$ 357$ mil (US\$ 108 mil) anualmente como vencimento básico, enquanto ministros do STF, R \$ 438 mil (US\$ 132 mil). ${ }^{10}$ Respectivamente, isso equivale a 11,3 e 13,9 vezes o PIB per capita (Gráfico 2).

Os valores apresentados para os magistrados brasileiros referem-se exclusivamente a seus vencimentos básicos. Como é sabido, todavia, eles recebem outros benefícios, incluindo auxílio-moradia, saúde, alimentação, transporte etc. (Gomide; Salles, 2015; Madeiro, 2018). $\mathrm{O}$ judiciário da maioria dos países europeus não fornece tais benefícios. Auxílio à moradia, por exemplo, existe apenas em Portugal, na Rússia e na Turquia. Inversamente, os únicos auxílios adicionais recebidos por magistrados na Alemanha, na Espanha, na França e na Itália são relativos à produtividade (CEPEJ, 2014, p. 320). Assim, os rendimentos dos magistrados brasileiros seriam, de fato, superiores aos seus vencimentos básicos. A despesa mensal média por magistrado no país sugere isso, sendo igual a $R \$ 48.516$, valor que totaliza $R \$$ 582 mil (US\$ 176 mil) por magistrado ao ano, correspondendo a 18,4 vezes o PIB per capita.

Os magistrados também são auxiliados por amplas estruturas administrativas. Servidores, terceirizados, estagiários, comissionados, cedidos e requisitados somam aproximadamente 430 mil indivíduos, ou cerca de 207 funcionários não magistrados no poder judiciário por 100 mil habitantes, proporção comparativamente elevada (CNJ, 2018a,

8 Esses valores incluem despesas com inativos no poder judiciário. Ao excluí-los, a despesa total do judiciário brasileiro atinge $\mathrm{R} \$ 76,5$ bilhóes, equivalente a $\mathrm{R} \$ 368,22$ por habitante e $1,17 \%$ do PIB (CNJ, 2018a, p. 56). Para as comparaçôes, utilizamos as taxas de câmbio de 29 de dezembro de 2017, iguais a US\$ $1=\mathrm{R} \$ 3,31$ e $€ 1=\mathrm{R} \$ 3,98$.

9 De forma a conferir maior confiabilidade às informaçōes dos países da América Latina, para os quais os dados secundários disponíveis são mais antigos, coletamos os dados — de 2015 ou do ano mais recente — diretamente de fontes primárias, relativas às execuçōes e leis orçamentárias, nas autoridades fazendárias dos países e estados, ou províncias. Isso aprimora o trabalho que havia sido originalmente elaborado pelos autores Da Ros (2015) e Da Ros e Taylor (2017), nos quais nos valíamos exclusivamente de dados secundários. Para tanto, recebemos ajuda valiosa de Diego Silva Ardila, Matthew C. Ingram e Jeronimo Rodriguez Use, a quem agradecemos o auxílio na produção e interpretação dos dados.

10 Disponível em: <http://www.cjf.jus.br/cjf/transparencia-publica-1/informacoes-sobre-pessoal/estrutura-remuneratoria/2015/tabela-de-remuneracao-de-magistrados>. Acesso em: 29 ago. 2018. 


\section{Gráfico 1 - Orçamento do judiciário brasileiro em perspectiva comparada (\% do produto interno bruto - PIB)*}

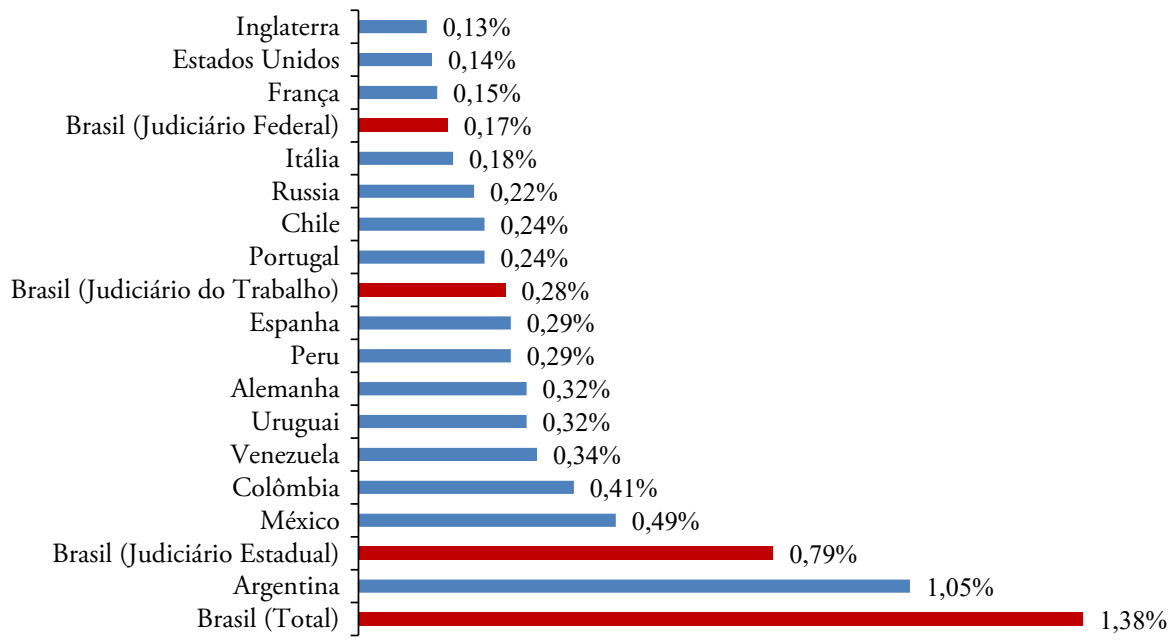

* O percental de Brasil (Total) é superior à somatória de Brasil (Judiciário Federal), Brasil (Judiciário Estadual) e Brasil (Judiciário do Trabalho), porque inclui despesas dos judiciário eleitoral e militar e dos tribunais superiores. Fonte: CEPEJ (2014; 2016); CNJ (2018a) e demais informaçôes foram coletadas conforme a nota 8.

Gráfico 2 - Vencimentos dos magistrados federais brasileiros em início e fim de carreira em perspectiva comparada*, países selecionados.

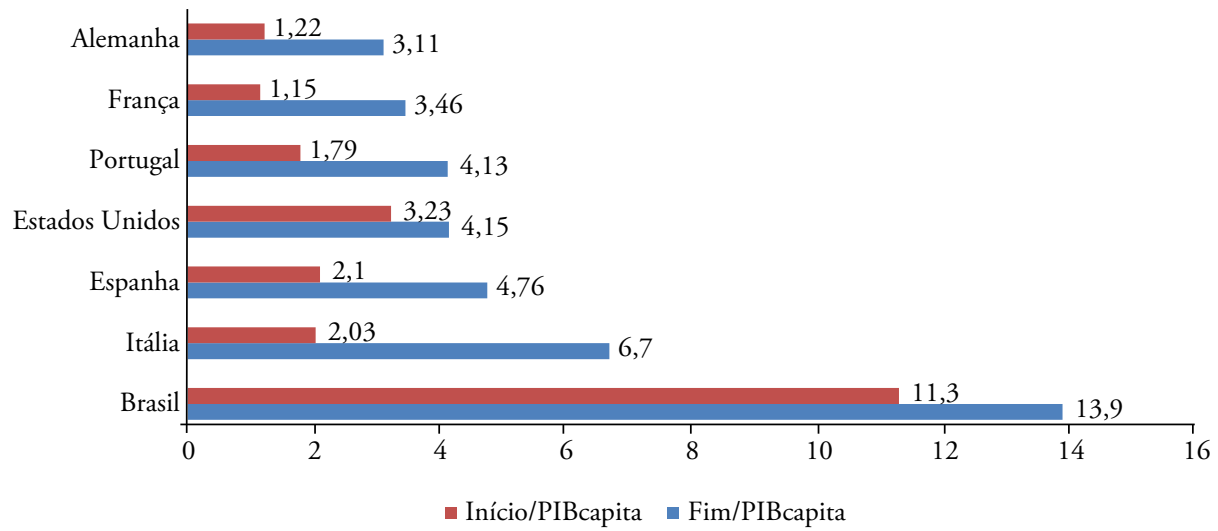

PIB: produto interno bruto; *entende-se fim de carreira como o cargo de integrante da Suprema Corte ou Tribunal Constitucional. Fontes: CEPEJ (2014, p. 302-310) e dados para o Brasil conforme nota 9. 
p. 66). A maioria dos países não se aproxima dessa proporção, oscilando entre 33 e 67 funcionários não magistrados por $100 \mathrm{mil} \mathrm{habi-}$ tantes. Os poucos países que se aproximam à taxa brasileira são: Argentina (150), Eslovênia (161) e Croácia (162) (CEJA, 2007; CEPEJ, 2014, p. 177). Apenas os servidores da área judiciária, ou seja, "que atuam diretamente com a tramitação do processo" (CNJ, 2017, p. 61), totalizam 180 mil no primeiro grau (11,5 por juiz), 31.119 no segundo grau (13,6 por desembargador) e 3.415 nos tribunais superiores ( 45,5 por ministro) (CNJ, 2018a, p. 66-67). Os rendimentos dos servidores também são elevados. A despesa mensal média por servidor no judiciário é igual a $\mathrm{R} \$$ 15.164, atingindo $\mathrm{R} \$ 19.932$ no judiciário trabalhista (CNJ, 2018a, p. 65). Esses valores são equivalentes a 5,8 e 7,6 vezes o PIB per capita, nessa ordem, proporçáo superior aos vencimentos de magistrados em diversos países europeus. Finalmente, apesar dos concursos frequentes, cargos e funçóes comissionadas consomem 13,2\% da despesa com o pessoal do judiciário, equivalente a $11,9 \%$ da despesa total (CNJ, 2018a, p. 64).

Ainda assim, o judiciário tem se caracterizado por uma combinação de quadros qualificados, acesso amplo, independência e respeito às suas decisóes. A maioria dos magistrados é selecionada pelo próprio judiciário, em concursos públicos muito competitivos; eles são vistos como profissionais altamente capacitados, que permanecem no topo da hierarquia entre os profissionais ju- rídicos (Fontainha et al., 2014). Paralelamente, houve a expansão do acesso aos tribunais, de maneira especial para a população de baixa renda, com a criação de juizados especiais e da defensoria pública. $\mathrm{O}$ acesso também foi ampliado por novos instrumentos legais, como a Ação Civil Pública (ACP) e, no STF, a Ação Direta de Inconstitucionalidade (ADIn). O Ministério Público (MP) também se tornou bastante autônomo e influente, contribuindo para o uso dos tribunais como locus para a resolução de disputas. Por fim, decisóes judiciais são preponderantemente cumpridas, tanto por agentes governamentais quanto por litigantes privados.

Retornaremos a essas características mais adiante. Por ora, destacamos o fato de que, enquanto todas representaram melhorias no funcionamento do sistema judicial, também realçaram aspectos menos positivos. $\mathrm{O}$ primeiro destes é tanto um sinal de sucesso quanto de considerável fraqueza do sistema judicial: o número de casos cresceu rapidamente nas últimas décadas, demonstrando não somente a atratividade do judiciário a potenciais litigantes, mas também exercendo pressão considerável sobre tribunais e juízes. Com efeito, as taxas de congestionamento o passivo de casos náo solucionados de anos anteriores - permaneceram altas, resultando em um acúmulo significativo de casos. $\mathrm{O}$ judiciário brasileiro recebeu 29,1 milhóes de casos novos e deu baixa a 31 milhóes de casos em 2017. ${ }^{11}$ Simultaneamente, lidou com um passivo de 80,1 milhôes de casos. Isso sugere

11 Tanto o volume de casos novos como o de baixados informados pelo CNJ provavelmente superestimam a demanda e a resolutividade judiciais, respectivamente. Isso ocorre porque o $\mathrm{CNJ}$ classifica como casos novos tanto aqueles que ingressaram em primeira instância como os recursos apresentados em um mesmo ano. Como esses recursos são apenas novos procedimentos nos casos já em andamento, não parece correto classificá-los como propriamente novos, uma vez que não exprimem demandas pela resolução de novos conflitos. Excluindo-se os recursos, o total de casos novos originários no poder judiciário foi igual a 24,3 milhóes em 2017 , volume $16,4 \%$ inferior ao reportado pelo CNJ (2018a, p. 97). Paralelamente, o CNJ classifica como "processos baixados" náo apenas aqueles definitivamente arquivados, mas também aqueles "remetidos para outros órgãos judiciais competentes” (CNJ, 2018a, p. 73). 
que o judiciário como um todo vem conseguindo lidar com menos de 30\% dos casos vigentes a cada ano, mesmo que haja diferenças entre os ramos da justiça (Tabela 1). Dado o crescimento contínuo na demanda, isso se traduz em atrasos consideráveis.

Associados ao acúmulo de casos não solucionados, estão densos procedimentos jurídicos, muitas vezes incompreensíveis para leigos. Cidadãos com frequência se surpreendem pelas reviravoltas, tanto em casos politicamente salientes quanto em seus próprios lítigios. Algumas das causas dessa volatilidade são fundamentadas em dispositivos legais aparentemente razoáveis, como pedidos de vista, os quais concedem tempo adicional aos magistrados de tribunais para examinar processos. ${ }^{12}$ No entanto, talvez a razão institucional mais ampla dessa insegurança jurídica - termo utilizado, sobretudo depreciativamente, em referência à imprevisibilidade das decisóes judiciais — seja a adoção de um sistema híbrido de controle de constitucionalidade de leis, que inclui tanto decisóes abstratas e concentradas no STF quanto decisões concretas e difusas. A última significa que qualquer juiz ou tribunal no país possui o poder de anular uma norma jurídica em um caso específico sob alegação de incompatibilidade com a Constituição (Arantes, 1997).

Por causa da impermanência constitucional brasileira - a atual Constituição é a sétima - e da miscelânea de leis desenvolvidas sob diferentes regimes políticos, há também larga amplitude de justificativas legais disponíveis para apoiar uma variedade de julgamentos. Essa amplitude é ainda mais evidente em momentos de transição política e legal, como o início de cada novo período constitucional, o que permite aos juízes maior latitude para tomar decisóes com base em interesses pessoais, concepçóes políticas ou diferentes teorias do direito e da justiça (Koerner, 2006, p. 277). Com efeito, muitas decisóes judiciais desde o retorno à democracia foram imbuídas de uma matriz de ativismo social, resultado tanto da generosa lista de direitos da Constituição de 1988 como de muitos juízes passarem a adotar a defesa do

Tabela 1 - Acúmulo de processos judiciais, em 2016 (em milhóes).

\begin{tabular}{l|c|c|c|c}
\hline & $\begin{array}{c}\text { Judiciário } \\
\text { Federal }\end{array}$ & $\begin{array}{c}\text { Judiciário } \\
\text { Estadual }\end{array}$ & $\begin{array}{c}\text { Judiciário } \\
\text { Trabalhista }\end{array}$ & Total $^{*}$ \\
\hline Casos baixados & 3,7 & 21,7 & 4,6 & 31,0 \\
\hline Casos novos & 3,9 & 20,2 & 4,3 & 29,1 \\
\hline Casos pendentes & 10,3 & 63,5 & 5,5 & 80,1 \\
\hline Novos + Pendentes & 14,2 & 83,7 & 9,8 & 109,2 \\
\hline Taxa de congestionamento* & $73,9 \%$ & $74,1 \%$ & $53,1 \%$ & $71,6 \%$ \\
\hline
\end{tabular}

Taxa de congestionamento $=(1-$ número de casos baixados/[casos pendentes + novos $]) ;{ }^{*}$ : p total inclui os judiciários trabalhista, estadual, federal, militar, eleitoral e os tribunais superiores.

Fonte: CNJ (2018a, p. 32-55).

12 Em tese, os magistrados devem retornar tais casos em 30 dias para julgamento, mas permanecem com os ministros do STF, por exemplo, por quase um ano em média (Falcão; Hartman; Chaves, 2014). Há, portanto, muita discricionariedade dos ministros individualmente em relaçáo à agenda do tribunal (Arguelhes; Hartmann, 2017). 
bem-estar da sociedade como virtude profissional (Bonelli, 2002; Engelmann, 2007; Engelmann; Cunha Filho, 2013). Combinados à amplitude dos recursos processuais admissíveis, tais fatores produzem uma cacofonia de opiniōes judiciais, a qual pode gerar grande incerteza (Lamounier; Souza, 2002; Castelar Pinheiro, 2003; Sadek, 1995).

Paralelamente, o judiciário brasileiro é marcado pela combinação de tradição fraca de precedentes com efeito vinculante e enorme respeito à autoridade dos magistrados e à individualidade dos julgamentos (por exemplo, Arantes, 1997; Castelar Pinheiro, 2000; Taylor, 2008). Conjuntamente, esses fatores significam que o judiciário é marcado por significativa redundância decisória, a qual podemos classificar - ineditamente, ao que nos parece - de duas formas, exógena e endógena.

Redundância decisória exógena ocorre quando casos juridicamente idênticos ou semelhantes são decididos por vários órgãos jurisdicionais, isolada e repetitivamente. Assim, mesmo quando uma questão jurídica igual se apresenta a tribunais distintos - $\mathrm{e}$ com frequência a turmas ou câmaras diferentes em um mesmo tribunal —, eles chegam a decisões divergentes. O resultado é um sistema judicial marcado por enormes inconsistências. Como os magistrados náo decidem esses casos de forma convergente, em vez de estabilizar expectativas e resolver conflitos, o judiciário acaba reproduzindo-os e amplificando-os. O efeito disso é maior demanda judicial, sobretudo de casos massificados (relaçôes de consumo, questôes previdenciárias etc.). $\mathrm{Na}$ falta de uma posição clara do judiciário como instituição, torna-se racional - dados os baixos custos de acesso e o valor relativamente reduzido de boa parcela das indenizaçóes decorrentes de eventuais condenaçóes - tentar a sorte em um órgão jurisdicional ou postergar a resolução de um conflito pela via judicial, em vez de transacionar privadamente para resolvê-lo.

Mesmo após a criação, em 2004, de instrumentos que introduziram a lógica do precedente no Brasil (ou seja, súmula vinculante e repercussão geral), ainda há forte viés contra a uniformizaçáo jurisprudencial, que decorre, em parte, da oposição dos magistrados da base do judiciário (Da Ros, 2013). Mesmo no STF, a tradiçáo é que os votos de cada ministro se baseiem em diferentes argumentos jurídicos. Portanto, a decisão do tribunal é simplesmente a soma das opiniôes favoráveis e contrárias, sem a formação de uma argumentação clara e institucional da corte que oriente futuras decisões do judiciário (Barbosa, 2007; Silva, 2013).

Por sua vez, redundância decisória endógena ocorre em relaçáo a um mesmo caso, que é reexaminado por diversos órgáos jurisdicionais até se chegar a uma resolução final. Peça fundamental desse quebra-cabeça é o interminável fluxo de recursos (apelaçôes, agravos, embargos etc.), permitido pelos códigos de processo civil e criminal. Recursos em demasia forçam os magistrados - e até órgãos colegiados nos tribunais - a reexaminarem os diferentes aspectos dos mesmos casos repetidamente.

Esses recursos podem ser dirigidos tanto ao próprio órgão que tomou a decisão contestada como a uma instância superior. Entre as primeiras, a chamada taxa de recorribilidade interna média para todo o judiciário de 2009 a 2017 foi de 12,6\%; já a taxa de recorribilidade externa atingiu 9,0\% (CNJ, 2018a, p. 98). Desagregadamente, a taxa de recorribilidade externa média no mesmo período chegou a $50,5 \%$ no judiciário trabalhista, $27,8 \%$ no federal e $8,0 \%$ no estadual, enquanto a taxa média de recorribilidade interna atingiu 14,$2 ; 12,8$ e $6,7 \%$, respecti- 
vamente (CNJ, 2018a, p. 99). Entre as diferentes instâncias do judiciário, o problema repete-se. Criados para conferirem maior celeridade à prestação jurisdicional, os juizados especiais estaduais e federais exibiram baixas taxas de recorribilidade interna em 2017 (5 e 3\%), mas não escaparam das elevadas taxas de recorribilidade externa, de 13 e $23 \%$, respectivamente. Entre os tribunais de segunda instância, em 2017, os TJs, TRFs e TRTs apresentaram taxas de recorribilidade interna de 19, 31 e 19\% e de recorribilidade externa de 23,23 e $40 \%$, nessa ordem (CNJ, 2018a, p. 97).

Com base nos dados de 2017, a probabilidade de um caso iniciado em uma vara estadual chegar ao STJ é de 1,4\% (cerca de um a cada 69 casos), de um caso que começou em uma vara federal até o STJ é de 3,9\% (aproximadamente um a cada 26 casos) e de um caso de em uma vara do tra- balho de $17,2 \%$ (mais ou menos um a cada 6 casos) (Gráfico 3). ${ }^{13}$ Mesmo tribunais superiores não escapam à realidade do exaustivo reexame de casos. No STJ, as taxas de recorribilidade interna e externa são de $27 \mathrm{e}$ $6 \%$. No STF, a taxa de recorribilidade (interna apenas) é de 12,4\% (STF, 2018, p. 45). Essa informação, contudo, é possivelmente subestimada. Isso ocorre porque os agravos regimentais (recursos cabíveis contra as decisóes do próprio STF) representam $56 \%$ do volume de casos da corte desde 2011. ${ }^{14}$

Um efeito importante disso é o fato de que grande parcela da expectativa de resolução definitiva dos conflitos recai sobre os tribunais superiores. Isso é sobretudo verdadeiro para o STF, cuja carga de trabalho formalmente não guarda paralelo entre os tribunais congêneres mundo afora. Ao longo dos últimos cinco anos, o STF tomou 565 mil decisóes, das quais $457 \mathrm{mil}$ foram

\section{Gráfico 3 - Casos resolvidos, por instância e ramo do poder judiciário.}

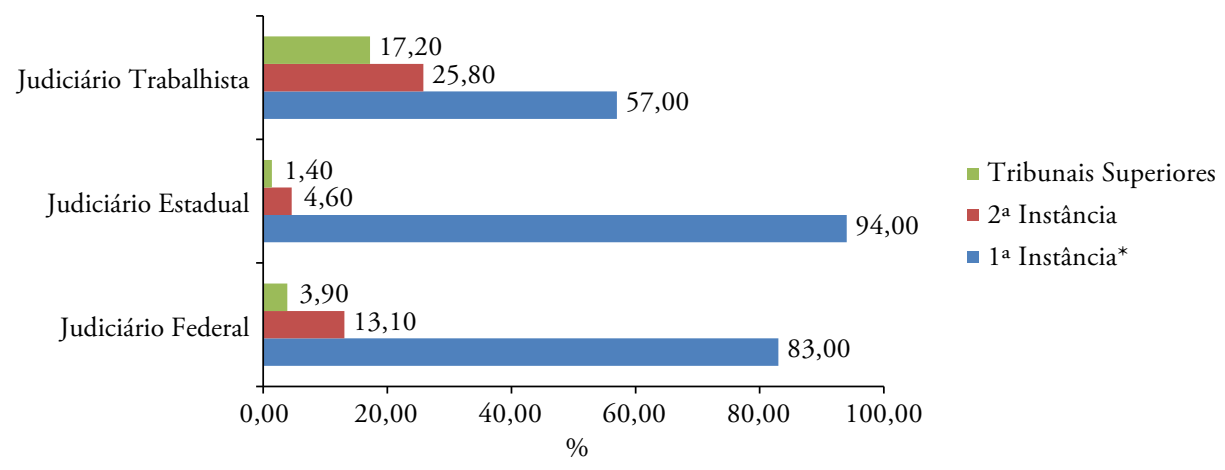

*Foram excluídos juizados especiais.

Fonte: CNJ (2018a).

13 De forma a calcular essas probabilidades, multiplicamos as taxas de recorribilidade externa das varas para os tribunais e dos tribunais para os respectivos tribunais superiores (CNJ, 2017, p. 97).

14 Disponível em: <http://www.stf.jus.br/portal/cms/verTexto.asp?servico=estatistica\&pagina=REAIProcessoDistrib uido >. Acesso em: 2 set. 2018. 
finais (Brasil, 2016, p. 42-43). Rosenn (2014) observa que o STF é capaz de lidar com o volume de casos somente porque isso "envolve problemas sobre os quais o STF já se decidiu" (Rosenn, 2014, p. 301). Muitos recursos apresentam a mesma questáo e podem, portanto, ser resolvidos por um único ministro: ao longo dos últimos cinco anos, $86,5 \%$ das decisões do STF foram realizadas monocraticamente, ${ }^{15}$ e apenas $2,3 \%$ dos casos foram decididos pelo plenário. Os $11,2 \%$ dos casos restantes foram decididos por uma das duas turmas do tribunal (STF, 2018, p. 44).

Essa dupla redundância decisória, exógena e endógena, resulta em morosidade. Embora haja esforço consciente ao menos desde 2004 para eliminar casos mais antigos, não é incomum ter ciência de processos que estejam em tramitação há mais de uma década. Há quase 20 anos, Castelar Pinheiro (2000, p. 85) estimou que o tempo médio que um caso leva para chegar a uma decisão final era de 46 meses no judiciário federal, 38 no estadual e 31 no trabalhista. Dados atualizados sugerem que essa espera não diminuiu muito. No primeiro grau, o tempo médio de baixa de um processo de conhecimento em primeira instância é de 44 meses na justiça federal, 43 na estadual e 11 na trabalhista. $\mathrm{A}$ isso, contudo, não se somam os tempos de recursos aos tribunais de segunda instância nem dos processos de execução eventualmente decorrentes. Aqueles adicionam, em média, 33 meses na justiça federal, 11 na estadual e oito na trabalhista; estes adicionam, em média, 64 meses na justiça federal, 46 na estadual e 35 na trabalhista (CNJ, 2018a, p. 34-43). Os juizados especiais estaduais e federais, por sua vez, parecem estar entre as poucas inovaçóes institucionais das últimas décadas, que contribuíram para a redução do tempo de processamento dos casos, o qual é inferior ao dos processos iniciados nas varas estaduais e federais (Gráfico 4).

Dadas a demanda judicial crescente e a persistência do congestionamento, é improvável que a demora na tramitação da maior parte dos processos se reduza significativamente no horizonte próximo. Convém observar, todavia, que uma variedade de estudos demonstra que a morosidade é considerada por uma parcela significativa da populaçáo como o principal problema do sistema judicial do país (Castelar Pinheiro, 2000; Sá e Silva, 2011; Del Porto, 2013).

\section{Gráfico 4 - Tempo médio de baixa dos processos por ramo do poder judiciário e fase processual (em meses).}

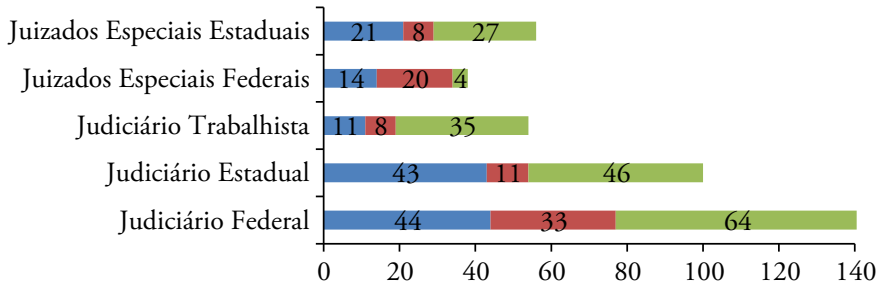

- 1a Instância

- 2a Instância

• Processo de Execuçáo

Fonte: CNJ (2018a).

15 Sobre os poderes individuais dos ministros do STF, ver Arguelhes e Ribeiro (2018). 


\section{Três décadas de reformas}

Os tribunais herdados do regime militar eram conservadores, e sua agenda limitava-se a questôes civis e penais tradicionais, além de conflitos intraburocráticos (Pereira, 2005; Recondo, 2018). Ainda assim, o regime militar, em contraste com alguns países vizinhos, manteve uma pátina de legalidade, e as instituiçôes judiciais foram preservadas, ainda que tímidas e subordinadas. Com efeito, a transformação do sistema judicial iniciou-se quase imediatamente após a transiçáo à democracia e continua ocorrendo desde entáo. De forma a sintetizar as mudanças do sistema judicial que aconteceram ao longo da última geração, classificamo-nas em duas categorias: inovaçóes institucionais e aperfeiçoamento do desempenho judicial.

As inovações institucionais deram-se em dois saltos. O primeiro deles coincide com os primeiros anos de retomada da democracia e envolveu a ampliaçáo dos poderes do MP, que foi praticamente refundado entre 1985 e $1988^{16}$ e afastado do controle do poder executivo, passando a atuar como um quarto poder de facto do Estado (Arantes, 2002; Castilho; Sadek, 1998; Ferraz, 1997; Kerche, 1999; 2007; Macedo Júnior, 1995; Sadek; Cavalcanti, 2003). Os MPs estaduais e federal receberam amplos poderes, incluindo a responsabilidade de defender os interesses difusos e coletivos, por meio de uma série de novos instrumentos legais. Talvez o mais proeminente deles tenha sido a ACP, que permite ao MP propor açóes em diversas áreas - ambiental, relaçôes de consumo etc. Outra ferramenta importante é o termo de ajustamento de conduta, mediante o qual promotores podem firmar acordos pré-ju- diciais com instituiçôes públicas e privadas, exigindo que alterem seu comportamento sob a ameaça de ação judicial. Paralelamente, o MP foi dotado de recursos significativos. A sua participação no PIB brasileiro é equivalente à de sistemas judiciais inteiros em outros países, totalizando $\mathrm{R} \$ 15,4$ bilhôes em 2014, ou 0,32\% do PIB (Da Ros, 2015).

No mesmo período, a Assembleia Constituinte de 1987-1988 também foi responsável por profundas inovações em relação às instituiçôes judiciais, as quais podem ser resumidas conforme segue: os atores habilitados a propor açôes diretas de inconstitucionalidade foram expandidos para além de casos comparáveis; criou-se uma variedade de novos tipos de açôes para proteger direitos fundamentais; aprofundou-se o hibridismo do sistema de revisão constitucional; e a pauta infraconstitucional foi removida da corte e colocada sob jurisdição de um tribunal novo criado para esse fim, o STJ (Da Ros, 2017). Como resultado, o papel da corte tornou-se muito mais político. Isso incluiu o STF atuar não apenas como corte constitucional, mas também como última instância recursal. Embora talvez fosse desejável para um país saindo de uma ditadura militar de 21 anos de duração dotar o órgão máximo do judiciário com tantos poderes e funções; isso imporia um fardo severo ao STF, que acabaria decidindo um alto número de casos em comparação aos tribunais congêneres em outros países (Tabela 2 ).

Ainda entre as inovaçóes institucionais iniciais, a criaçáo da Advocacia-Geral da União em 1993 removeu qualquer ambiguidade sobre quem era responsável por defender o setor público federal em juízo, após a reconfiguração do MP. Paralelamen-

16 A lei orgânica do MP, contudo, foi aprovada somente em 1993. 
te, advocacias e procuradorias dos estados foram remodeladas ou criadas para cumprir essa tarefa em âmbito subnacional. Apesar de sofrer dos mesmos problemas de defensorias públicas em outros países - orçamento enxuto, falta de pessoal ${ }^{17}$ e baixa relevância política -, a inclusão da Defensoria Pública na Constituição de 1988 foi um passo importante. De todas as instituiçóes legais criadas então, ela foi a que demorou mais tempo para se institucionalizar. Em nível federal, embora tenha sido criada em 1993, somente ganhou estatura a partir de 2014, com a aprovação da Emenda Constitucional no 80. Em nível subnacional, o quadro é desigual. Enquanto alguns estados já possuíam defensoria antes mesmo da última Constituição, outros a estabeleceram logo após a sua promulgação e outros apenas na década de 2010 (Moura et al., 2013; Madeira, 2014). Finalmente, inspirada na experiência do início dos anos 1980 com os Juizados de Pequenas Causas, a Constituição demandou o estabelecimento de Juizados Especiais Civis e Criminais. Uma vez criados em nível estadual, em meados da década de 1990 e em nível federal na virada do século, eles se tornaram componentes centrais do judiciário, ampliando o acesso (Cunha, 2008). Hoje, são responsáveis por uma larga parcela dos casos decididos em definitivo pelo judiciário todos os anos - 29,5\% no judiciário estadual e 61,1\% no federal, em 2017 (CNJ, 2018a, p. 36-44).

O segundo salto de inovaçôes institucionais decorreu da Reforma do Judiciário de 2004, resultado da Emenda Constitucional $\mathrm{n}^{\mathrm{o}} 45$, que garantiu autonomia às defensorias públicas e estabeleceu órgãos de fiscalização para judiciário e MP. O ímpeto reformista adveio de uma variedade de fontes, incluindo ministros de tribunais superiores insatisfeitos com o funcionamento do judiciário, políticos, advogados, acadêmicos e o público em geral, que criticavam a ineficácia, corrupção e irracionalidade sistêmica dos tribunais.

A reforma resultou de um longo processo iniciado em 1992 em proposta de emenda constitucional do deputado Hélio Bicudo, a primeira de mais de 40 reformas propostas nos anos seguintes. Doze anos depois - e após uma conturbada comissão parlamentar de inquérito em 1999, a CPI do Judiciário - , o governo federal foi capaz de impul-

Tabela 2 - Processos recebidos e julgados por supremas cortes e tribunais constitucionais.

\begin{tabular}{l|c|c|c}
\hline País & Tribunal & Processos recebidos & Processos julgados \\
\hline Brasil & Supremo Tribunal Federal & 103.650 & 115.402 \\
\hline Argentina & Suprema Corte de Justicia & 16.543 & 16.584 \\
\hline Estados Unidos & Supreme Court & 8.580 & 79 \\
\hline México & Suprema Corte de Justicia & 6.720 & 7.237 \\
\hline Alemanha & Bundesverfassungsgericht & 6.686 & 6.117 \\
\hline
\end{tabular}

Fonte: Supremas Cortes dos respectivos países, último ano disponível a partir de 2015.

17 Entre os 8.489 cargos de defensor público existentes em 2013, 3.435 (40,5\%) ainda não estavam ocupados, em grande parte por conta de salários pouco atrativos e condiçóes de trabalho precárias, resultando em 1.926 comarcas sem defensor público, equivalente a mais de $70 \%$ do país (Moura et al., 2013). 
sionar a reforma. O ministro da Justiça Márcio Thomaz Bastos - que, como presidente da Ordem dos Advogados do Brasil (OAB), havia advogado sem sucesso pela criação de um órgão de controle externo do judiciário durante a Assembleia Constituinte - trabalhou ao lado do ministro do STF Nelson Jobim e do ministro do STJ Edson Vidigal durante o primeiro ano da presidência de Lula, para reunir o que veio a ser conhecido como Pacto Republicano entre executivo, legislativo e judiciário.

Eles foram duramente criticados por muitos juízes, que consideravam o ato um esforço para limitar a independência dos magistrados de instâncias inferiores. Ao trabalhar para convencer juízes e legisladores, foram beneficiados por uma variedade de escândalos, incluindo casos de nepotismo, superfaturamento de obras e vendas de decisões, que demonstraram que ninguém tinha a noção exata da escala nem do funcionamento do judiciário. Faltava-lhes planejamento e perspectiva estratégica sobre seus efeitos na sociedade (OAB, 2014; Seligman, 2014a; 2014b; 2015; Vieira, 2004).

Embora a reforma tenha sido menos abrangente do que inicialmente pretendida, a criação do Conselho Nacional da Justiça $(\mathrm{CNJ})$ e do Conselho Nacional do MP (CNMP) foi uma importante conquista política, especialmente à luz da forte oposição de juízes e procuradores. Ainda que estes dominem a composição dos órgãos, detendo dois terços dos assentos, exercem papel importante, adotando medidas que visam melhorar a legitimidade e a eficiência do sistema judicial. No caso específico do CNJ, tais medidas incluíam, por exemplo, o estabelecimento de regras mais claras para a progressão dos magis- trados, limites ao número de servidores não concursados, enfrentamento ao nepotismo, melhoria da transparência e enfrentamento a casos flagrantes de corrupção judicial — com a punição administrativa de juízes e servidores por meio da recém-criada Corregedoria Nacional de Justiça (Franco, 2015; Ingram, 2016). Por outro lado, medidas destinadas a melhorar o desempenho dos tribunais compreenderam o estabelecimento de critérios de produtividade, maior informatização, reduçáo do estoque de casos sem resolução e maior alocação de recursos ao judiciário (Da Ros; Taylor, 2017; Da Ros; Ingram, 2019a).

A segunda categoria de reformas almejava aperfeiçoar o desempenho da prestaçáo jurisdicional. Nesta, houve múltiplas mudanças nas regras de processo civil, incluindo a introdução das câmaras de conciliação, os limites aos recursos interlocutórios e o uso de processos eletrônicos (Da Ros; Taylor, 2017). Embora impulsionadas pelo desejo de melhorar o acesso e a eficiência, os efeitos de tais medidas ainda não são claros.

Essas reformas também se desenvolveram em duas ondas desde 1985, culminando no novo Código de Processo Civil, promulgado em 2015. ${ }^{18}$ As primeiras reformas almejavam evitar que certos tipos de confitos chegassem ao judiciário e ocorreram especialmente em meados da década de 1990, enfatizando a conciliação e a arbitragem como formas de reduzir a carga de trabalho do judicário. Essas reformas, contudo, diluíram o poder dos juízes do tribunal de primeira instância, ao permitirem recursos interlocutórios (particularmente, agravos de instrumento) contra diversas decisões, o que acarretou aumento do volume de trabalho dos tribunais de segunda instância e superiores.

18 O Código de Processo Civil anterior foi escrito em 1973 e havia sido alterado mais de 60 vezes desde entáo. 
A segunda onda de reformas ocorreu na sequência da emenda constitucional de 2004, que criou um direito constitucional à duração razoável dos processos. Em geral, as medidas adotadas reconheceram a inevitabilidade da chegada dos conflitos ao judiciário e tentaram resolver a demanda. Para tanto, a legislação aprovada no período reforçou a autoridade dos juízes de primeira instância em casos menos salientes, limitou o número de recursos disponíveis e incentivou o uso da informática (processo eletrônico, apreensão de bens on-line etc.).

Paralelamente, o STF passou a contar com novos instrumentos processuais, reforçando a posição na hierarquia judicial ante as demais instâncias do judiciário (Nunes, 2010). Os melhores exemplos são a súmula vinculante e a repercussão geral. $\mathrm{O}$ primeiro é um mecanismo de precedente com efeito vinculante em questóes constitucionais, que foram resolvidas repetidamente pelo STF. O segundo é "um análogo ao dispositivo processual dos EUA de certiorari... concedendo ao STF o poder de recusar ouvir recursos extraordinários que não têm repercussôes gerais” (Rosenn, 2014, p. 302).

Esses novos instrumentos tiveram efeitos importantes. Desde que entraram em vigor em abril de 2007, o STF emitiu 56 súmulas vinculantes e concedeu repercussão geral a 777 recursos extraordinários. Embora não tenham resolvido o problema do volume de trabalho da corte, parecem estar contribuindo para reduzir a demanda e incrementar a produtividade da corte, ainda que lentamente. Nos dez anos completos anteriores à implementação da reforma, de 1997 a
2006, 92,7 mil casos foram recebidos, 78,1 mil distribuídos, 85 mil julgados e $12,5 \mathrm{mil}$ acórdãos foram publicados no STF em média, anualmente. Já nos dez anos completos posteriores à reforma, entre 2008 e 2017, a média de processos recebidos a cada ano caiu para 83,3 mil $(-10,1 \%)$ e a de distribuídos para $51,5 \mathrm{mil}(-34,1 \%)$, ao passo que a de julgados aumentou para 104,1 mil (+22,5\%) e a de acórdãos publicados cresceu para 14,4 mil (+15,2\%), conforme Figura 1 .

$\mathrm{O}$ impacto da reforma, contudo, expande-se muito além do STF, abrangendo todo o judiciário. Os 777 casos em que o STF concedeu repercussão geral até julho de 2018 tratavam de controvérsias que afetam 1.545.192 casos nas instâncias inferiores, volume equivalente a $1,5 \%$ da carga processual de todo o judiciário no país. ${ }^{19}$ Destes, mais de 700 mil dizem respeito a correçóes monetárias em decorrência dos planos de estabilização econômica do fim da década de 1980 e início de 1990. Ao mesmo tempo, em alguns tribunais, por exemplo, o TRF da 4a Regiáo, o número de processos suspensos aguardando decisão do STF em casos de repercussão geral ultrapassa 180 mil, correspondendo a $10 \%$ do total de casos pendentes no tribunal em 2017 (CNJ, 2018a).

\section{Judiciário na sociedade}

O impacto do judiciário na sociedade brasileira é significativo, abrangendo temas tão complexos e variados quanto as políticas públicas, economia, corrupção e legitimidade democrática. Nessa ordem, revisamos os quatro pontos adiante.

19 Informaçōes disponíveis em: <http://www.stf.jus.br/portal/cms/verTexto.asp? servico=estatistica\&pagina=sobresta dosrg>, sobre casos sobrestados; <http://www.stf.jus.br/portal/cms/vertexto.asp?servico=jurisprudenciasumulavin culante $>$, para a súmula vinculante; e $<$ http://www.stf.jus.br/portal/cms/verTexto.asp?servico=jurisprudenciaRepe rcussaoGeral\&pagina=numeroRepercussao >, para repercussão geral. Acesso em: 14 mar. 2016. 
Figura 1 - Movimentação processual do Supremo Tribunal Federal (1985-2017).

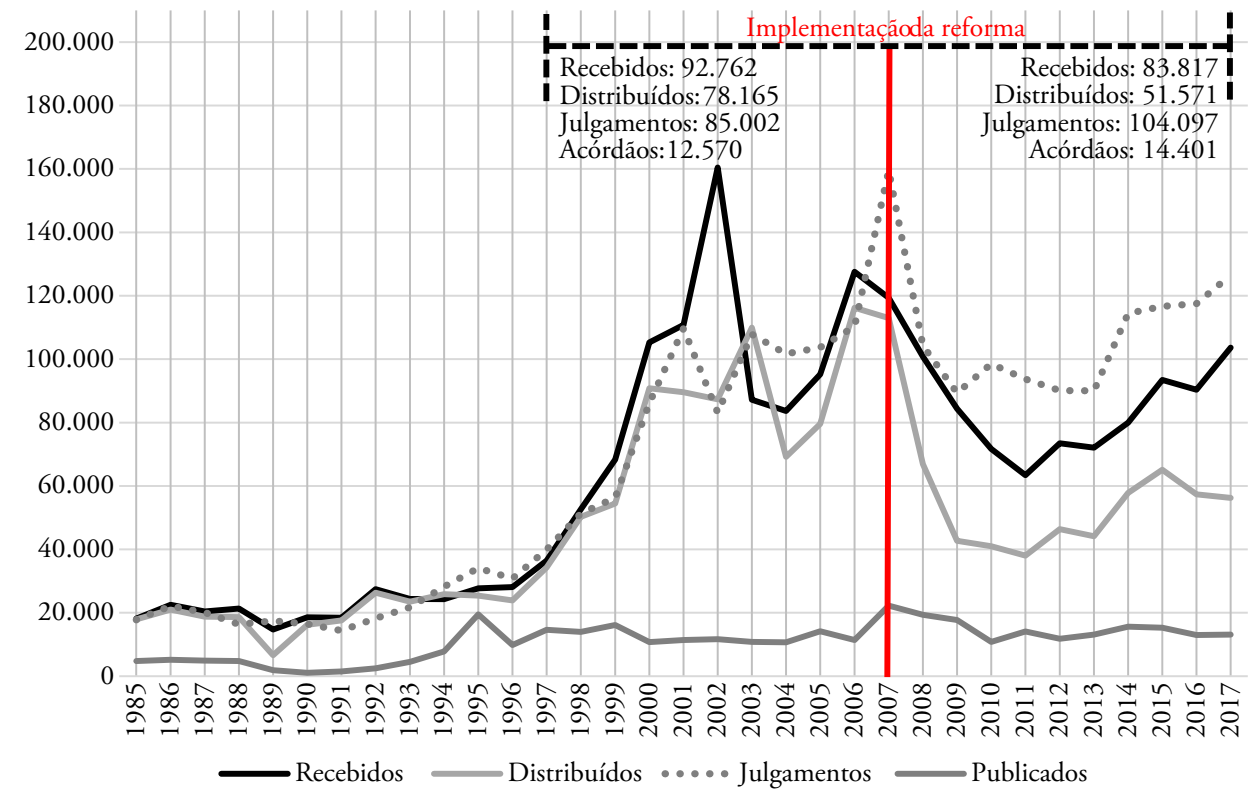

Fonte: Supremo Tribunal Federal, Movimento Processual, disponível em <www.stf.jus.br $\geq$. Acesso em: 3 set. 2018.

As mudanças institucionais no judiciário sob a democracia tiveram o efeito de lançá-lo "no centro da vida pública e conferir-lhe o papel de protagonista" (Sadek, 1999, p. 297). Isso se refletiu tanto no crescimento contínuo da demanda judicial desde a década de 1980 quanto no uso que agentes políticos passaram a fazer do judiciário como arena para contestar as diferentes políticas públicas adotadas desde entâo. Isso é especialmente verdadeiro no âmbito do STF, que gradativamente foi se convertendo em importante ponto de veto do sistema político brasileiro, no processo de elaboração de políticas públicas (Taylor, 2006).

Embora o STF tenha decidido de forma preponderantemente estratégica em diversos casos de saliência política desde 1988
(Kapiszewski, 2012), ele também é um dos "tribunais mais poderosos do mundo", com vasta gama de funçôes, mas nenhuma "doutrina das questôes políticas" declarada, que o permitiria evitar determinadas controvérsias (Rosenn, 2014, p. 298-300). Não à toa, um ex-ministro da corte observa que um ministro da corte deve saber "distinguir entre casos graves e frívolos e determinar quais casos apresentam desafios legítimos à constitucionalidade das leis e quais casos apresentam principalmente motivações políticas" (Barbosa, 2007, p. 189). De fato, farta evidência empírica sugere que as $\mathrm{ADIns}$ propostas por atores com motivaçóes políticas claras (por exemplo, por partidos políticos) estão entre as menos bem-sucedidas no STF contra leis federais, particularmente quando compa- 
radas às $\mathrm{ADIns}$ propostas por membros $\mathrm{da}$ comunidade jurídica, como OAB, Procurador-Geral da República (PGR) e associaçóes de magistrados (Carvalho, 2009; Oliveira, 2009; Carvalho; Barbosa; Gomes Neto, 2014; Canello, 2016; Mariano Silva, 2016).

O STF impôs uma média de 13 vetos judiciais a diplomas legais federais ao ano entre 1994 e 2008, apenas via ADIns (Taylor; Da Ros, 2008, p. 831). ${ }^{20}$ Colocando isso em perspectiva, o número médio anual de leis federais declaradas inconstitucionais pela Suprema Corte dos Estados Unidos e pelo Tribunal Constitucional Federal da Alemanha é bastante inferior - igual a 0,8 e 7,7, respectivamente. ${ }^{21}$ Como resultado, o STF converteu-se em importante instituição política do país, envolvendo-se em uma variedade aparentemente interminável de questôes sensíveis, incluindo o julgamento dos planos de estabilização econômica e a reforma agrária (Taylor, 2008), regras eleitorais (Marchetti; Cortez, 2009; Marchetti, 2013), poderes de decreto do presidente ( $\mathrm{Da}$ Ros, 2008), regimento interno do Congresso (Aragão, 2013), reformas previdenciárias (Barbosa, 2007), leis anticorrupção, descriminalização de uniôes civis de mesmo sexo, ação afirmativa e preservação da Lei da Anistia de 1979 (Rosenn, 2014), entre inúmeros outros. Com efeito, dificilmente o STF escaparia ao diagnóstico de "judicialização da megapolítica”, proposto por Hirschl (2008).

As instâncias inferiores também passaram a fazer parte de estratégias políticas mais amplas, com diferentes partidos políticos e grupos de interesse, buscando atrasar, desa- creditar ou apenas declarar oposição a políticas públicas por meio de açôes populares e açôes movidas contra autoridades (Taylor, 2008, p. 90-108). Paralelamente, dadas a amplitude e a vagueza dos direitos definidos na Constituição, cidadãos comuns com frequência demandam a implementação de políticas públicas de seu interesse por meio de açôes judiciais, com custos significativos e que crescem a taxas desconcertantes. Limitando a discussão a uma área com amplo debate acadêmico - o fornecimento de medicamentos por meio de decisóes judiciais —, de acordo com o Ministério da Saúde, "o crescimento real do gasto com as açôes judiciais de medicamentos foi de $547 \%$ entre 2010 e 2016, passando de $\mathrm{R} \$ 199,6$ milhōes para R\$ 1,3 bilhão" (apud Vieira, 2018, p. 25). Somente no estado de Sáo Paulo, o total dos tipos de medicamentos demandados na justiça - muitos destinados a tratamentos de alto custo - saltou de 799 para 14.563 nos últimos anos (Wang et al., 2014). O cenário não se limita às grandes cidades. Com taxas de sucesso dos requerentes atingindo $85 \%$, estima-se que $57 \%$ dos municípios no país lidem com essa questão regularmente (Wang et al., 2014).

Além do seu efeito sobre as políticas públicas, os efeitos econômicos do judiciário são sentidos especialmente em decorrência de sua morosidade. Um levantamento realizado antes da reforma de 2004 constatou que esta era a principal preocupaçấo do setor empresarial. Embora a lentidão tenha ajudado algumas delas, estimativas de Castelar Pinheiro (2000, p. 187-191) sugeriram que

20 Foram incluídas as decisões de mérito e liminar. Esses dados referem-se apenas a ADIns. Deve-se notar que várias leis acabaram declaradas inconstitucionais pelo tribunal, por meio de outros instrumentos jurídicos, particularmente os recursos oriundos de instâncias inferiores (Dimoulis; Cunha; Ramos, 2014).

21 As médias foram calculadas dividindo-se o número de leis declaradas inconstitucionais pelo total de anos de funcionamento dos tribunais ( $c f$. Congressional Research Service, 2014, p. 2287-2336; FCC, 2014, p. 29). 
a melhoria do desempenho dos tribunais ao nível de países desenvolvidos aumentaria o PIB na ordem de $25 \%$. Seu estudo demonstrou ainda que mais de três quintos dos casos tratavam de um número muito pequeno de questóes, sobretudo relacionadas a planos de estabilização e ao setor público. Isso contribuiria para afastar o investimento privado e geraria uma indústria de agentes, que ganhariam a vida com a ineficiência do sistema judicial (Castelar Pinheiro, 2000, p. 196).

Nesse particular, duas fontes dos efeitos econômicos do judiciário têm sido importantes. Por um lado, a chamada indenização punitiva é apenas esporadicamente utilizada nos círculos judiciais brasileiros, nos quais a indenizaçáo possui caráter preponderantemente compensatório (Vaz, 2009; Serpa, 2011). Portanto, os casos são decididos quase exclusivamente tendo em vista a demanda específica apresentada aos magistrados, que raramente levam em consideração o efeito dissuassório que indenizaçóes maiores poderiam gerar sobre conflitos semelhantes. Isso é verdadeiro sobretudo nas relaçóes de consumo, uma área que lida com problemas relativamente simples, tais como à má prestação de serviços por parte dos bancos ou empresas de telefonia, mas que contribui para a carga de trabalho do judiciário. Por vezes, é vantajoso aos prestadores de serviços contratarem um exército de advogados para responder a cada caso, atrasarem a tomada de decisão e imporem custos a eventuais litigantes, em vez de resolverem os problemas que geraram os casos (Prudente, 2014). Tendo em conta as pequenas quantias pagas nessas indenizaçôes e o número relativamente limitado de pessoas que ingressam com açóes, o efeito dissuassório das decisóes judiciais sobre comportamentos claramente ilegais acaba sendo limitado. Embora isso recentemente venha mudando, os magistrados e o sistema judicial como um todo têm sido avessos ao uso sistemático de indenização punitiva.

Por outro lado, o setor público é um dos litigantes mais prolíficos do sistema judicial. As entidades com maior número de processos perante o sistema judicial no país, quer como requerentes, quer como requeridos, são instituiçóes públicas - ou seja, governos federal, estaduais e municipais, bancos públicos etc. (AMB, 2015; Oliveira, 2016). Apenas no STF, entre os litigantes com mais de mil processos no tribunal entre 1988 e 2009, 90\% dos casos têm pelo menos uma instituição pública como uma das partes. Uniáo, Caixa Econômica Federal e Instituto Nacional do Seguro Social são os litigantes mais frequentes, com mais de $50 \%$ do total de casos na corte (Falcão; Cerdeira; Arguelhes, 2011, p. 67-68). Parte da razáo do predomínio do governo como litigante, historicamente, está relacionada ao alto volume de casos decorrentes dos planos de estabilização econômica pós-democráticos e à enorme instabilidade legal gerada por eles e por planos de reforma do Estado e da previdência no tocante a salários, aposentadorias, poupanças etc. Entre os 12 maiores litigantes perante $o$ tribunal, apenas um não é uma instituição pública, a Telemar Norte Leste S.A., que é uma empresa de telefonia cujos litígios se encaixam quase perfeitamente na narrativa sobre a indenização punitiva já descrita (Falcão; Cerdeira; Arguelhes, 2011, p. 67-68).

Uma terceira área de impacto judicial é a corrupçáo, tanto como um problema dentro do judiciário quanto como uma questáo que este é chamado a decidir. Em relação à primeira, magistrados em praticamente todos os níveis já foram acusados de vender decisóes, com grandes escândalos envolvendo integrantes até mesmo do STJ. Duas im- 
portantes operaçôes policiais na virada do século chamaram atenção para esse problema: a Operação Anaconda, que encontrou evidências de vendas de sentenças por um juiz federal em São Paulo, enquanto o chamado Caso TRT concluiu que um juiz trabalhista roubou mais de US\$ 90 milhóes da construção do Fórum Trabalhista, também em São Paulo. Em ambos os casos, os juízes foram presos. No entanto, em um número muito grande de casos, a única punição possível para magistrados suspeitos de corrupção é a aposentadoria compulsória. Entre 1988 e 2013, dos 6.703 casos recebidos pelo CNJ com informaçóes sobre potenciais irregularidades, excluídas acusaçóes de demora excessiva para tomar decisóes, apenas 38 resultaram na aposentadoria compulsória dos magistrados envolvidos (Franco, 2015, p. 100-122).

Complementarmente, outra questão é a relativa fragilidade do judiciário no controle da corrupção política. Apesar do recente protagonismo na área, a posição dos tribunais é delicada, porque a constituição assegura aos agentes políticos em exercício no cargo foro privilegiado. Assim, autoridades federais respondem a açóes penais apenas ante o STF, governadores estaduais ante o STJ, e os deputados estaduais e prefeitos ante as cortes de segunda instância. Como todos são tribunais, contudo, não exibem estrutura adequada (ou seja, de vara criminal) para processar e instruir tais casos. $\mathrm{Pa}-$ ralelamente, a morosidade e a redundância decisória são semelhantes à de outros casos, sendo exacerbadas pela cautela política dos tribunais e pela capacidade dos réus de apresentar um intenso fluxo de recursos (Taylor, 2017). Não supreendentemente, a primeira condenação de um político federal no STF ocorreu somente em 2010. Nos estados, po- rém, há considerável variação nos níveis de respostas judiciais à corrupção, influenciada por fatores contextuais, tais como o grau de autonomia, coordenação e mobilização das instituiçóes do sistema de justiça. Com efeito, ao passo que alguns estados possuem centenas de condenaçóes criminais de prefeitos, outros náo ultrapassaram uma dezena (Da Ros, 2014; 2018).

A última área de impacto judicial envolve os seus efeitos sobre a legitimidade do sistema democrático, que pode ser entendida, em parte, como um subproduto de seu desempenho nas três áreas já examinadas, entre outras. Embora os tribunais estejam entre as instituiçôes mais estáveis e contribuam para a manutenção do estado de direito, há muito por fazer. A questão mais óbvia é a ineficiência dos tribunais na prestação de sua atividade-fim. Refletindo sobre o impacto da Emenda Constitucional no 45, o ex-secretário de reforma do judiciário Sérgio Renault observou que a questão central da morosidade não foi resolvida (Migalhas, 2014). Seu sucessor, Flávio Caetano, constatou que os casos ainda levam, em média, dez anos para chegar a uma resolução (Affonso; Macedo, 2015). Embora a reforma de 2004 tenha contribuído para melhorar a transparência do judiciário, seu impacto sobre a eficiência decisória é questionável. Ainda, a enorme redundância decisória verificada no país compromete possivelmente o próprio papel estabilizador que o poder judiciário poderia exercer.

Nessa perspectiva, outra área de preocupação é o elitismo do judiciário. Apesar do incremento na diversidade (Sadek, 2006), sua pauta segue focada em casos que afetam os estratos superiores da sociedade. Um exemplo é a discussão recente sobre o uso da prisão preventiva contra criminosos 
de colarinho branco no âmbito da Operação Lava Jato. A prática é comum: $37 \%$ das mais de 700 mil pessoas encarceradas no país também estâo detidas de maneira preventiva (Fórum Brasileiro de Segurança Pública, 2014). Isso provavelmente apenas gerou discussão em decorrência do perfil dos réus. Tal elitismo pode ser explicado em parte pelo fato de os magistrados serem $80 \%$ brancos em um país composto de $55 \%$ de náo brancos (CNJ, 2018a, p. 8). Isso também se reflete na fraca resposta do sistema judicial a casos de direitos humanos, como homicídios praticados por policiais, com especial impacto sobre pobres e nấo brancos (Brinks, 2008).

Do mesmo modo, somente cerca de $30 \%$ dos cidadãos afirmam confiar no judiciário (FGV, 2014b, p. 24), e seu funcionamento é severamente criticado: $70 \%$ dos cidadãos relatam estar pouco satisfeitos $(44,4 \%)$ ou nada satisfeitos $(25,7 \%)$ com ele (Latinobarómetro, 2011). Não obstante, $59 \%$ das pessoas acreditam que a maioria dos magistrados é honesta (FÓRUM BRASILEIRO DE SEGURANÇA PÚBLICA, 2014, p. 7), e apenas $25 \%$ das pessoas que tinham um conflito não o trouxeram ao judiciário, porque não confiavam em um tratamento justo (Del Porto, 2013, p. 286287). Ao mesmo tempo, $53 \%$ absteve-se de trazer casos ao judiciário, pois acreditava que isso levaria muito tempo. Dos que iniciaram um processo, no entanto, apenas 63\% alcançaram uma decisão (Del Porto, 2013, p. 286-287). Entrar no sistema judicial não parece particularmente difícil; sair dele com uma decisão, contudo, parece ser o principal desafio. ${ }^{22}$

\section{Para onde vamos daqui?}

Esta seção resume algumas das questóes mais prementes que o judiciário ainda enfrenta. A reforma de 2004 teve três efeitos importantes: disponibilização de dados, formação de instituiçốes de supervisão do sistema judicial e criação de instrumentos vinculantes para limitar o número de processos repetitivos. Já discutimos o último ponto, mas os dois primeiros merecem maior atenção.

Muitas das inovaçóes de 2004 centraram-se na melhoria da disponibilidade dos dados necessários para analisar as deficiências do sistema judicial. Tais esforços para a coleta de informaçôes já haviam sido realizados pela Secretaria de Reforma do Judiciário do Ministério da Justiça e pelo próprio STF, porém, após a reforma, essas tarefas foram consolidadas no CNJ e CNMP. Com efeito, parte da discussáo sobre o desempenho do sistema judicial somente é possível em decorrência do contínuo esforço de coleta e sistematização de dados realizado por esses órgãos.

A segunda mudança importante foi a criação de órgáos de supervisão. Embora ainda haja espaço para pesquisas sistemáticas sobre a implementaçáo das metas do $\mathrm{CNJ}$, o panorama geral parece desigual. Por um lado, o CNJ desempenhou papel fundamental, especialmente onde o judiciário era mais problemático, em estados como Maranhão e Bahia (Ingram, 2016). Por outro, os objetivos mais ambiciosos, voltados à totalidade do país, foram bem-sucedidos apenas no começo, mas logo desapareceram. As resoluçóes do CNJ de 2006 que fixaram limites máximos à remuneração, por exemplo, tiveram impacto importante no início, mas hoje parecem relí-

22 Isso é verdadeiro em relação aos casos civis, mas não necessariamente no tocante aos criminais, uma vez que nesses casos a entrada no sistema de justiça não se dá via judiciário, mas pelo contato com a polícia. 
quias do passado. Uma hipótese é que o $\mathrm{CNJ}$ teria sido capturado pelos interesses dos próprios magistrados, especialmente de estados mais ricos (Folha de S.Paulo, 2015; Neves, 2015; Vasconcellos, 2015; Carvalho; Leitão, 2013; Fragale Filho, 2013).

Outro problema abordado apenas timidamente na reforma de 2004 é a crescente demanda. Apesar dos esforços, o número de novos casos que chegam ao judiciário praticamente não parou de crescer desde a redemocratização: foram 5,1 milhóes em 1990, 18 milhôes em 2004 e 29,1 milhóes em 2017 (Gabbay; Cunha, 2012; CNJ, 2018a). Enquanto o número de casos novos cresceu $252 \%$ de 1990 a 2004, essa taxa foi reduzida para $61 \%$ desde 2004 . As reformas da década de 2000, portanto, náo reduziram a demanda, e sim apenas seu ritmo de crescimento.

O crescimento da demanda judicial tem sido enfrentado sobretudo de três formas: incentivando a resolução negociada de conflitos, aperfeiçoando o uso de tecnologias da informaçáo e comunicação e aumentando o número de magistrados e funcionários. Em relação ao primeiro, os índices de conciliação já são altos, com $12,1 \%$ dos casos sendo resolvidos dessa forma (CNJ, 2018a, p. 139). Esse esforço, todavia, não diminui necessariamente a carga de trabalho do judiciário, porque os acordos de conciliação são firmados no judiciário, e não privadamente. Arbitragem e formas não judiciais de resolução de conflitos têm crescido, de maneira especial no setor empresarial, mas seguem relativamente raras (Engelmann, 2012).
No que tange ao segundo, o uso de processos eletrônicos e sistemas de gerenciamento de casos permite reduzir o chamado tempo morto dos casos (cargas, vistas etc.), o que em tese diminuiria a duração. Isso, contudo, também não afeta a demanda, apenas permite que se acelere o processamento dos feitos - e, a julgar pelos dados sobre a duração dos casos, também não vem atingindo esses objetivos de maneira satisfatória. No que se refere ao terceiro ponto, o judiciário não somente consome recursos significativos, como vem experimentando uma expansão quase contínua de seus quadros desde 1988, sem que isso diminua a demanda.

Essas três soluçôes, frisa-se, lidam preponderantemente com o lado da oferta do problema, e não da demanda. Desse lado, o crescimento do número de casos pode ser consequência da explosão no número de profissionais jurídicos. Atualmente, há cerca de 1,1 milhão de advogados no país, ${ }^{23}$ proporção de 5,3 advogados por mil habitantes. Essa taxa, que já é alta em termos comparativos, representa quase o quíntuplo de 1991, quando havia 1,1 advogado por mil habitantes (FGV, 2014a, p. 63). É improvável que esses números decresçam no futuro próximo, dado o ritmo de crescimento da força de trabalho. Estima-se que as mais de 1.100 faculdades de Direito do país coloquem no mercado cerca de 95 mil bacharéis por ano (FGV, 2014a; Ghirardi; Cunha; Feferbaum, 2014). ${ }^{24}$

Essas preocupaçôes com o crescimento da demanda também ensejaram esforços para aumentar a eficiência decisória dos magistrados. Com efeito, os magistrados brasi-

23 Disponível em: <http://www.oab.org.br/institucionalconselhofederal/quadroadvogados>. Acesso em: 10 set. 2018.

24 Os números brasileiros são altos em comparação aos de uma sociedade já repleta de advogados: os Estados Unidos têm aproximadamente 1,2 milhấo, representando 3,9 advogados por mil habitantes (ABA, 2011). A título de comparaçáo, os dados sobre a Uniáo Europeia mostram que a média é de dois advogados por mil habitantes (FGV, 2014a, p. 64). 
leiros já são muito eficientes. Estima-se que 1.819 casos sejam baixados por ano por magistrado no judiciário do país (CNJ, 2018a, p. 86). Comparativamente, poucos países exibem números tão elevados (CEJA, 2007; CEPEJ, 2014; AMB, 2015). Estudo do CNJ demonstrou, por exemplo, que apenas dois países (Áustria e Dinamarca) exibem taxas mais elevadas de produtividade por magistrado do que a brasileira (CNJ, 2011, p. 26).

Todavia, conforme explicado, só é possível aos magistrados lidarem com essa imensa carga de trabalho no Brasil porque há muitos funcionários atuando diretamente na área-fim para auxiliá-los e porque muitos casos versam sobre os mesmos temas ou consistem nos mesmos casos, sendo reexaminados repetidamente. A sobrecarga de trabalho, por conseguinte, deve-se ao menos em parte à imensa redundância decisória do sistema judicial do país. O fato de os juízes serem eficientes, portanto, não implica que a instituição na qual atuam também o seja. Assim, o diagnóstico paradoxal que emerge é de que o Brasil possui juízes eficientes, mas um judiciário ineficiente.

Infelizmente, a maioria das reformas que poderiam melhorar a eficácia judicial se relaciona com a organização de outros procedimentos judiciais, os quais são reféns de questóes que dificilmente chegam à agenda de reformas. Estes incluem a extrema independência dos juízes uns dos outros (tanto vertical como horizontalmente) e a resultan- te atomização da tomada de decisáo. Dada a diversificação no perfil dos magistrados nas instâncias inferiores do judiciário no Brasil ao longo dos últimos anos, o compromisso com essas bandeiras parece ser das poucas causas capazes de unificarem os magistrados e suas associaçôes no país hoje em dia.

A discussão sobre a eficiência e a eficácia dos tribunais tem sido a pedra angular da maioria dos debates sobre a reforma judicial no Brasil. Por mais central que seja, no entanto, não é o único, ou mesmo o mais importante, aspecto das suas deficiências. Pelo menos duas outras dimensóes de um judiciário democrático precisam ser consideradas: grau de acesso e equidade de tratamento. No que se refere ao acesso, embora tenha havido enorme expansão, há desigualdades regionais que afetam dramaticamente a acessibilidade, a equidade de tratamento e, até mesmo, a eficácia do sistema judicial, como salientam os estudos de Ingram (2016), Da Ros (2014), Madeira (2014), entre outros. Essa diferença de acesso também revela uma diferença importante no tratamento recebido nos tribunais. Talvez o melhor exemplo venha do sistema de justiça criminal do país, no qual as defensorias públicas possuem poucos recursos comparativamente ao MP. Não à toa, os aumentos massivos no encarceramento foram conseguidos em grande parte às custas daqueles que poderiam se valer dos serviços de defensorias públicas mais estruturados Brasil afora.

\section{Bibliografia}

AFFONSO, Julia; MACEDO, Fausto. Secretário da Reforma do Judiciário pede novo "pacto republicano". O Estado de S. Paulo, 2 jan. 2015.

AMERICAN BAR ASSOCIATION (ABA). Lawyer Demographics. ABA, 2011. Disponível em: <http://www. americanbar.org/content/dam/aba/migrated/marketresearch/PublicDocuments/lawyer_demographics_2011. authcheckdam.pdf $>$. Acesso em: 2 abr. 2015. 
ARAGÃO, José C. M. Judicializaçáo da Política no Brasil: influência sobre atos interna corporis do Congresso Nacional. Brasília: Câmara dos Deputados, 2013.

ARANTES, Rogério Bastos. Judiciário e Política no Brasil. São Paulo: EDUC, 1997.

ARANTES, Rogério Bastos. Ministério Público e Política no Brasil. São Paulo: EDUC, 2002.

ARGUELHES, Diego W.; HARTMANN, Ivar A. Timing Control without Docket Control: How Individual Justices Shape the Brazilian Supreme Court's Agenda. Journal of Law and Courts, v. 5, n. 1, p. 105-140, 2017. https:// doi.org/10.1086/690195

ARGUELHES, Diego W.; RIBEIRO, Leandro M. Ministrocracia? O Supremo Tribunal Individual e o processo democrático brasileiro. Novos Estudos CEBRAP, v. 37, n. 1, p. 13-32, 2018. http://dx.doi.org/10.25091/ s01013300201800010003

ASSOCIAÇÃO DOS MAGISTRADOS BRASILEIROS (AMB). O Uso da Justiça e o Litígio no Brasil. Brasília: Associação dos Magistrados Brasileiros, 2015.

BANCO MUNDIAL. Improving the Performance of Justice Institutions: Recent Experiences of Selected OECD Countries Relevant for Latin America. Washington, D.C.: World Bank, 2011.

BARBOSA, Joaquim. Reflections on Brazilian Constitutionalism. UCLA Journal of International Law and Foreign Affairs, v. 12, p. 181-197, 2007.

BONELLI, Maria da Glória. Profissionalismo e política no mundo do direito. Sáo Carlos: Sumaré/Edufscar/ Fapesp, 2002.

BRASIL. Supremo Tribunal Federal (STF). Relatório de atividades 2015. Brasília: Supremo Tribunal Federal, 2016. Disponível em: <http://www.stf.jus.br/arquivo/cms/sobreStfConhecaStfRelatorio/anexo/relatorio2015.pdf>. Acesso em: 25 jun. 2018.

BRINKS, Daniel M. The Judicial Response to Police Killings in Latin America: Inequality and the Rule of Law. Cambridge: Cambridge University Press, 2008.

CANELLO, Julio. Judicializando a Federaçáo? O Supremo Tribunal Federal e os Atos Normativos Estaduais. Tese (Doutorado em Ciência Política) - Universidade do Estado do Rio de Janeiro, Rio de Janeiro, 2016.

CANON, Bradley C.; JOHNSON, Charles A. Judicial Policies: Implementation and Impact. 2. ed. Washington, D.C.: Congressional Quarterly Press, 1999.

CARVALHO, Ernani. Judicializaçáo da Política no Brasil: Controlo de Constitucionalidade e Racionalidade Política. Análise Social, v. 191, p. 315-335, 2009.

CARVALHO, Ernani; BARBOSA, Luis Felipe Andrade; GOMES NETO, José Mário Wanderley. OAB e as Prerrogativas Atípicas na Arena Política da Revisāo Judicial. Revista Direito GV, v. 10, n. 1, p. 69-98, 2014. http://dx.doi.org/10.1590/S1808-24322014000100004

CARVALHO, Ernani; LEITÃO, Natália. O Poder dos Juízes: Supremo Tribunal Federal e o Desenho Institucional do Conselho Nacional da Justiça. Revista de Sociologia e Política, v. 21, n. 45, p. 13-27, 2013. http://dx.doi. org/10.1590/S0104-44782013000100003

CASTELAR PINHEIRO, Armando (org.). Judiciário e Economia no Brasil. São Paulo: Sumaré, 2000.

CASTELAR PINHEIRO, Armando (org.). Reforma do Judiciário: Planos, Propostas e Perspectivas. São Paulo: Booklink Publicaçóes, 2003.

CASTILHO, Ela Wiecko; SADEK, Maria Tereza. O Ministério Público Federal e a administraçáo da Justiça no Brasil. São Paulo: Sumaré, 1998. 
CASTRO, Marcus Faro de. O Supremo Tribunal Federal e a judicialização da política. Revista Brasileira de Ciencias Sociais, v. 12, p. 147-56, 1997.

CENTRO DE ESTUDIOS DE JUSTICIA DE LAS AMÉRICAS (CEJA). Reporte sobre el Estado de la Justicia en las Américas, 2006-2007. Santiago: Centro de Estudios de Justicia de las Américas, 2007.

CLARK, Tom S. The Limits of Judicial Independence. Cambridge: Cambridge University Press, 2012.

COHEN, Jonathan M. Inside Appellate Courts: The Impact of Court Organization on Judicial Decision Making in the United States Courts of Appeals. Ann Arbor: University of Michigan Press, 2002.

CONGRESSIONAL RESEARCH SERVICE. The Constitution of the United States of America: Analysis and Interpretation. Centennial Edition. Washington, D.C.: United States Government Printing Office, 2014.

CONSELHO NACIONAL DE JUSTIÇA (CNJ). Estudo Comparado sobre Recursos, Litigiosidade e Produtividade: A Prestação Jurisdicional no Contexto Internacional. Brasília: Departamento de Pesquisas Judiciárias, Conselho Nacional de Justiça, 2011.

CONSELHO NACIONAL DE JUSTIÇA (CNJ). Justiça em Números 2017: Ano-Base 2016. Brasília: Departamento de Pesquisas Judiciárias, Conselho Nacional de Justiça, 2017.

CONSELHO NACIONAL DE JUSTIÇA (CNJ). Justiça em Números 2018: Ano-Base 2017. Brasília: Departamento de Pesquisas Judiciárias, Conselho Nacional de Justiça, 2018a.

CONSELHO NACIONAL DE JUSTIÇA (CNJ). Perfil Sociodemográfico dos Magistrados Brasileiros 2018. Brasília: Departamento de Pesquisas Judiciárias, Conselho Nacional de Justiça, 2018b.

CUNHA, Luciana Gross. Juizado Especial: Criação, Instalação, Funcionamento e a Democratização do Acesso à Justiça. São Paulo: Saraiva, 2008.

DA ROS, Luciano. Difícil hierarquia: a avaliação do Supremo Tribunal Federal pelos magistrados da base do Poder Judiciário no Brasil. Revista Direito GV, v. 9, n. 1, p. 47-64, 2013. http://dx.doi.org/10.1590/S180824322013000100003

DA ROS, Luciano. Em que ponto estamos? Agendas de pesquisa sobre o Supremo Tribunal Federal no Brasil e nos Estados Unidos. In: ENGELMANN, Fabiano (org.). Sociologia Política das Instituiçóes Judiciais. Porto Alegre: Ed. UFRGS/CEGOV, 2017.

DA ROS, Luciano. Mayors in the Dock: Judicial Responses to Local Corruption in Brazil. Tese (Doutorado) University of Illinois, Chicago, 2014.

DA ROS, Luciano. O Custo da Justiça no Brasil: Uma Análise Comparativa Exploratória. Newsletter do Observatório de Elites Políticas e Sociais do Brasil, v. 2, n. 9, p. 1-15, 2015.

DA ROS, Luciano. Poder de decreto e accountability horizontal: dinâmica institucional dos três poderes e medidas provisórias no Brasil pós-1988. Revista Sociologia e Política, v. 16, n. 31, p. 143-160, 2008. http://dx.doi. org/10.1590/S0104-44782008000200011

DA ROS, Luciano; INGRAM, Matthew C. Law, Courts, and Judicial Politics. In: AMES, Barry (org.). Routledge Handbook of Brazilian Politics. Nova York: Routledge, 2019a.

DA ROS, Luciano; INGRAM, Matthew C. Power, Activation, Decision Making, and Impact: Subnational Judicial Politics in Brazil. In: STERETT, Susan M.; WALKER, Lee D. (orgs.). Research Handbook on Law and Courts. Cheltenham: Edward Elgar, 2019b.

DA ROS, Luciano; TAYLOR, Matthew M. Opening the Black Box: Three Decades of Reform to Brazil's Judicial System. School of International Service Research Paper, n. 2017-3, 2017. Disponível em: <https://papers.ssrn.com/sol3/ papers.cfm?abstract_id=3028731 >. Acesso em: 24 jun. 2018. https://dx.doi.org/10.2139/ssrn.3028731 
DEL PORTO, Fabiana Brigante. A Avaliação do Judiciário e o Acesso à Cidadania na Visão dos Brasileiros. In: MOISÉS, José A.; MENEGUELLO, Rachel (orgs.). A Desconfiança Política e os seus Impactos na Qualidade da Democracia. São Paulo: Ed. USP, 2013.

DIMOULIS, Dimitri; CUNHA, Luciana Gross; RAMOS, Luciana de Oliveira. O Supremo Tribunal Federal para Além das Açóes Diretas de Inconstitucionalidade. São Paulo: Direito GV, 2014.

DOTAN, Yoav; HOFNUNG, Menachem. Legal Defeats-Political Wins: Why do Elected Representatives Go to Court? Comparative Political Studies, v. 38, n. 1, p. 75-103, 2005. https://doi. org/10.1177\%2F0010414004270969

ENGELMANN, Fabiano. O Espaço da Arbitragem no Brasil: Notáveis e Experts em Busca de Reconhecimento. Revista de Sociologia e Política, v. 20, n. 44, p. 155-176, 2012. http://dx.doi.org/10.1590/S010444782012000400012

ENGELMANN, Fabiano. Tradition and Diversification in the Uses of Law: A Proposed Analysis. Brazilian Political Science Review, v. 1, n. esp., p. 53-70, 2007.

ENGELMANN, Fabiano; CUNHA FILHO, Marcio Camargo. Açôes Judiciais, Conteúdos Políticos: Uma Proposta de Análise para o Caso Brasileiro. Revista de Sociologia e Política, v. 21, n. 45, p. 57-72, 2013. http://dx.doi. org/10.1590/S0104-44782013000100006

EPP, Charles R. The Rights Revolution: Lawyers, Activists and Supreme Courts in Comparative Perspective. Chicago: University of Chicago Press, 1998.

EPSTEIN, Lee; LANDES, William M.; POSNER, Richard A. The Behavior of Federal Judges: A Theoretical and Empirical Study of Rational Choice. Cambridge: Harvard University Press, 2013.

EUROPEAN COMMISSION FOR THE EFFICIENCY OF JUSTICE (CEPEJ). European judicial systems: efficiency and quality of justice. CEPEJ, n. 23, 2016. Disponível em: <http://www.coe.int/t/dghl/cooperation/ cepej/evaluation/2016/publication/REV1/2016_1\%20-\%20CEPEJ\%20Study\%2023\%20-\%20General\%20 report\%20-\%20EN.pdf>. Acesso em: 11 ago. 2017.

EUROPEAN COMMISSION FOR THE EFFICIENCY OF JUSTICE (CEPEJ). Report on European judicial systems - Edition 2014 (2012 data): efficiency and quality of justice. CEPEJ, 2014. Disponível em: <http:// www.coe.int/t/dghl/cooperation/cepej/evaluation/2014/Rapport_2014_en.pdf>. Acesso em: 18 mar. 2015.

FALCÃO, Joaquim; CERDEIRA, Pablo de Camargo; ARGUELHES, Diego Werneck. I Relatório Supremo em Números: O Múltiplo Supremo. Rio de Janeiro: Fundação Getelio Vargas, 2011.

FALCÃO, Joaquim; HARTMAN, Ivar A.; CHAVES, Vitor P. III Relatório Supremo em Números: O Supremo e o Tempo. Rio de Janeiro: Fundação Getulio Vargas, 2014.

FEDERAL CONSTITUTIONAL COURT (FCC). Annual Statistics 2013. Karlsruhe: Bundesverfassungsgericht, 2014.

FEELEY, Malcolm M.; RUBIN, Edward L. Judicial Policy Making and the Modern State: How the Courts Reformed America’s Prisons. Cambridge: Cambridge University Press, 2000.

FERRAZ, Antonio A. M. de Camargo. Ministério Público: instituição e processo. São Paulo: Atlas, 1997.

FOLHA DE S.PAULO. CNJ pelo Avesso. Folha de S.Paulo, 2015. Disponível em: <http://www1.folha.uol.com.br/ opiniao/2015/04/1613111-editorial-cnj-pelo-avesso.shtml>. Acesso em: 20 mar. 2016.

FONTAINHA, Fernando de Castro et al. Processos seletivos para a contrataçáo de servidores públicos: Brasil, o país dos concursos? Relatório de Pesquisa. Rio de Janeiro: Direito GV Rio, 2014. 
FÓRUM BRASILEIRO DE SEGURANÇA PÚBLICA. Anuário Brasileiro de Segurança Pública 2014. São Paulo: Fórum Brasileiro de Segurança Pública, 2014.

FRAGALE FILHO, Roberto. Conselho Nacional de Justiça: Desenho Institucional, Construção de Agenda e Processo Decisório. Dados, v. 56, n. 4, p. 975-1007, 2013. http://dx.doi.org/10.1590/S0011-52582013000400008

FRANCO, Ivan Candido da Silva de. Como sáo Julgados os Juízes? Uma Análise do Controle Disciplinar do Conselho Nacional de Justiça (2005-2013). Dissertação (Mestrado) - Fundação Getulio Vargas, São Paulo, 2015.

FUNDAÇÃO GETULIO VARGAS (FGV). Exame da Ordem em Números. Rio de Janeiro: FGV Projetos; Conselho Federal da Ordem dos Advogados do Brasil, 2014a.

FUNDAÇÃO GETULIO VARGAS (FGV). Relatório ICJ Brasil: 1º Trimestre/2014-4o Trimestre/2014 - Ano 06. São Paulo: Direito GV, 2014b.

GABBAY, Daniela Monteiro; CUNHA, Luciana Gross. Litigiosidade, Morosidade, e Litigância Repetitiva no Judiciário: Uma Análise Empírica. São Paulo: FGV, 2012.

GAURI, Varun; BRINKS, Daniel M. (orgs.). Courting Social Justice: Judicial Enforcement of Social and Economic Rights in the Developing World. Cambridge: Cambridge University Press, 2009.

GHIRARDI, José Garcez; CUNHA, Luciana Gross; FEFERBAUM, Marina (orgs.). Ensino Superior - Instituiçóos: Cursos de Direito, Instituiçóes de Ensino Superior, Mantenedoras e Grupos Educationais. Sáo Paulo: Observatório do Ensino do Direito, Fundação Getulio Vargas, 2014.

GIBSON, James L. From Simplicity to Complexity: The Development of Theory in the Study of Judicial Behavior. Political Behavior, v. 5, n. 1, p. 7-49, 1983. https://doi.org/10.1007/BF00989985

GINSBURG, T. Judicial Review in New Democracies: Constitutional Courts in Asian Cases. Cambridge: Cambridge University Press, 2003.

GOMIDE, Raphael; SALLES, Lívia Couto. Juízes estaduais e promotores: eles ganham 23 vezes mais do que você. Época, 2015. Disponível em: <https://epoca.globo.com/tempo/noticia/2015/06/juizes-estaduais-e-promotoreseles-ganham-23-vezes-mais-do-que-voce.html>. Acesso em: 14 jun. 2015.

HALL, matthew E. K. The Nature of Supreme Court Power. Cambridge: Cambridge University Press, 2011.

HAMMERGREN, Linn. Envisioning Reform: Conceptual and Practical Obstacles to Improving Judicial Performance in Latin America. College Park: Penn State University Press, 2007.

HELMKE, Gretchen. Institutions on the Edge: The Origins and Consequences of Inter-Branch Crisis in Latin America. Cambridge: Cambridge University Press, 2017.

HILBINK, Lisa; INGRAM, Matthew C. Courts and Rule of Law in Developing Countries. In: THOMPSON, William R. (org.). Oxford Research Encyclopedia of Politics. Oxford: Oxford University Press, 2019.

HIRSCHL, Ran. Towards Juristocracy: The Origins and Consequences of the New Constitutionalism. Cambridge: Harvard University Press, 2004.

HIRSCHL, Ran. The Judicialization of Mega Politics and the Rise of Political Courts. Annual Review of Political Science, v. 11, p. 93-118, 2008. https://doi.org/10.1146/annurev.polisci.11.053006.183906

HOROWITZ, Donald. The Courts and Social Policy. Washington, D.C.: Brookings Institution, 1977.

INGRAM, Matthew C. Crafting Courts in New Democracies: The Politics of Subnational Judicial Reform in Brazil and Mexico. Nova York: Cambridge University Press, 2016. 
INGRAM, Matthew C. Judicial Power in Latin America. Latin American Research Review, v. 50, n. 1, p. 250-260, 2015.

KAPISZEWSKI, Diana. High Courts and Economic Governance in Argentina and Brazil. Nova York: Cambridge University Press, 2012.

KAPISZEWSKI, Diana. Tactical Balancing: High Court Decision Making in Politically Crucial Cases. Law \& Society Review, v. 45, n. 2, p. 471-506, 2011. https://doi.org/10.1111/j.1540-5893.2011.00437.x

KAPISZEWSKI, Diana; TAYLOR, Matthew M. Compliance: Conceptualizing, Measuring, and Explaining Adherence to Judicial Rulings. Law \& Social Inquiry, v. 38, n. 4, p. 803-835, 2013. https://doi.org/10.1111/ j.1747-4469.2012.01320.x

KAPISZEWSKI, Diana; TAYLOR, Matthew M. Doing Courts Justice? Studying Judicial Politics in Latin America. Perspectives in Politics, v. 6, n. 4, p. 741-767, 2008. https://doi.org/10.1017/S1537592708081899

KERCHE, Fábio. Autonomia e discricionariedade do Ministério Público no Brasil. Dados, v. 50, n. 2, p. 259-279, 2007. http://dx.doi.org/10.1590/S0011-52582007000200002

KERCHE, Fábio. O Ministério Público e a Constituinte de 1987/88. In: SADEK, Maria Teresa (org.). O Sistema de Justiça. São Paulo: Sumaré, 1999. p. 61-77.

KOERNER, Andrei. Decisáo judicial, instituiçóes e estrutura socioeconômica: por uma análise política do pensamento jurídico brasileiro. São Paulo: IBCCRIM, 2006. p. 259-281.

LAMOUNIER, Bolívar; SOUZA, Amaury de. As elites brasileiras e o desenvolvimento nacional: fatores de consenso e dissenso. São Paulo: IDESP, 2002.

LATINOBARÓMETRO. Análisis Online. Latinobarómetro, 2011. Disponível em: <http://www.latinobarometro. org/latOnline.jsp>. Acesso em: 6 fev. 2015.

MACEDO JÚNIOR, Ronaldo Porto. A evoluçáo institucional do Ministério Público Brasileiro. São Paulo: Sumaré, 1995.

MADEIRA, Lígia Mori. Institutionalisation, Reform and Independence of the Public Defender's Office in Brazil. Brazilian Political Science Review, v. 8, n. 2, p. 48-69, 2014. http://dx.doi.org/10.1590/198138212014000100011

MADEIRO, Carlos. Brasil paga R\$ 104 milhôes por mês em auxílios a magistrados. UOL Notícias, 2018. Disponível em: $<$ https://noticias.uol.com.br/cotidiano/ultimas-noticias/2018/08/24/brasil-paga-r-104-mi-por-mes-em-auxilios-amagistrados-mps-omitem-valores.htm>. Acesso em: 24 ago. 2018.

MAHONEY, James; THELEN, Kathleen (orgs.). Explaining Institutional Change: Ambiguity, Agency, and Power. Cambridge: Cambridge University Press, 2009.

MARCHETTI, Vitor. Justiça e Competiçáo Eleitoral. Santo André: Ed. UFABC, 2013.

MARCHETTI, Vitor; CORTEZ, Rafael. A judicializaçáo da competição política: O TSE e as coligaçóes eleitorais. Opiniáo Pública, v. 15, n. 2, p. 422-450, 2009. http://dx.doi.org/10.1590/S0104-62762009000200006

MARIANO SILVA, Jeferson. Jurisdiçáo constitucional em Espanha (1981-1992) e Brasil (1988-1997). Tese (Doutorado de Ciência Política) - Universidade do Estado do Rio de Janeiro, Rio de Janeiro, 2016.

MIGALHAS. Reforma do Judiciário (EC 45/04) - 10 anos depois. Migalhas, 2014. Disponível em: <www.migalhas. com.br>. Acesso em: 4 fev. 2015.

MOURA, Tatiana Whately et al. Mapa da Defensoria Pública no Brasil. Brasília: ANADEP; IPEA, 2013. 
NAVIA, P.; RÍOS-FIGUEROA, J. The Constitutional Adjudication Mosaic in Latin America. Comparative Political Studies, v. 38, n. 2, p. 189-217, 2005. http://doi.org/10.1177/0010414004271082

NEVES, Marcelo. CNJ está esvaziado e capturado após 10 anos de existência? Consultor Jurídico, 2015. Disponível em: <http://www.conjur.com.br/2015-out-17/observatorio-constitucional-cnj-trocou-melhoria-gestao-judiciaria-agendarelevante>. Acesso em: 17 out. 2015.

NUNES, Rodrigo M. Politics without Insurance: Democratic Competition and Judicial Reform in Brazil. Comparative Politics, v. 42, n. 3, p. 313-331, 2010. http://doi.org/10.5129/001041510X12911363509756

OLIVEIRA, Fabiana Luci de. Agenda Suprema: Interesses em Disputa no Controle de Constitucionalidade das Leis no Brasil. Tempo Social, v. 28, n. 1, p. 105-133, 2016. http://dx.doi.org/10.11606/0103-2070.ts.2016.106021

OLIVEIRA, Vanessa Elias de. Poder Judiciário: Árbitro dos Conflitos Constitucionais entre Estados e União. Lua Nova, n. 78, p. 223-250, 2009. http://dx.doi.org/10.1590/S0102-64452009000300011

ORDEM DOS ADVOGADOS DO BRASIL (OAB). Presidente nacional da OAB avalia os 10 anos da Reforma do Judiciário. OAB, 2014. Disponível em: <http://www.oab.org.br/noticia/27957/presidente-nacional-da-oabavalia-os-10-anos-da-reforma-do-judiciario>. Acesso em: 5 fev. 2015.

PEREIRA, Anthony W. Political (In)Justice: Authoritarianism and the Rule of Law in Brazil, Chile and Argentina. Pittsburgh: Pittsburgh University Press, 2005.

PÉREZ-LIÑAN, A.; CASTAGNOLA, A. Judicial Instability and Endogenous Constitutional Change: Lessons from Latin America. British Journal of Political Science, v. 46, n. 2, p. 395-416, 2016. https://doi.org/10.1017/ S0007123414000295

PRILLAMAN, William C. The Judiciary and Democratic Decay in Latin America: Declining Confidence in the Rule of Law. Westport: Praeger, 2000.

PRUDENTE, Rodrigo Rodrigues de Oliveira e Silva. Motivaçáo das demandas judiciais repetitivas em Goiás. Dissertação (Mestrado) - Instituto Brasileiro de Direito Público, 2014.

RAMSEYER, Mark J.; RASMUSEN, Eric B. Comparative Litigation Rates. John M. Olin Center for Law, Economics, and Business, n. 681, 2010.

RECONDO, Felipe. Tanques e Togas: O STF e a Ditadura Militar. São Paulo: Companhia das Letras, 2018.

ROSENBERG, Geranl N. The Hollow Hope: Can Courts Bring About Social Change? Chicago: University of Chicago Press, 1991.

ROSENN, Keith S. Recent important decisions by the Brazilian Supreme Court. The University of Miami InterAmerican Law Review, v. 45, n. 2, p. 297-334, 2014.

SADEK, Maria Tereza. Magistrados: Uma Imagem em Movimento. Rio de Janeiro: FGV, 2006.

SADEK, Maria Tereza. O Sistema de Justiça. São Paulo: Sumaré, 1999.

SADEK, Maria Tereza (org.). A crise do Judiciário vista pelos juízes: resultados da pesquisa quantitativa. São Paulo: Sumaré, 1995.

SADEK, Maria Tereza; CAVALCANTI, Rosângela Batista. The New Brazilian Public Prosecution: An Agent of Accountability. In: WELNA, Scott; MAINWARING, Christopher (orgs.). Democratic Accountability in Latin America. Oxford: Oxford University Press, 2003. p. 201-227. 
SÁ E SILVA, Fábio. Opinião Pública, Pesquisa Aplicada e Reforma da Justiça: Contribuições e Desafios, Políticos e Analíticos. In: SCHIAVINATTO, Fabio (org.). Sistema de Indicadores de Percepçáo Social. Brasília: Instituto de Pesquisa Econômica Aplicada, 2011.

SELIGMAN, Felipe. A Reforma do Judiciário e os acordos para aprová-la. Jota, 2014a. Disponível em: <http://www. jota.info/reforma-judiciario-e-os-acordos-para-aprova-la>. Acesso em: 29 jan. 2015.

SELIGMAN, Felipe. Os impasses da Reforma do Judiciário. Jota, 2015. Disponível em: <http://www.jota.info/osimpasses-da-reforma-judiciario>. Acesso em: 29 jan. 2015.

SELIGMAN, Felipe. Uma década depois da "caixa preta". Jota, 2014b. Disponível em: <http://www.jota.info/umadecada-depois-da-caixa-preta>. Acesso em: 29 jan. 2015.

SERPA, Pedro Ricardo e. Indenizaçáo Punitiva. Dissertação (Mestrado) - Universidade de São Paulo, São Paulo, 2011.

SILVA, Virgílio Afonso da. Deciding without Deliberating. International Journal of Constitutional Law, v. 11, n. 3, p. 557-584, 2013. https://doi.org/10.1093/icon/mot019

SUPREMO TRIBUNAL FEDERAL (STF). Relatório de Atividades 2017. Brasília: Supremo Tribunal Federal, 2018.

TAYLOR, Matthew M. Corruption and Accountability. In: KINGSTONE, Peter; POWER, Timothy (orgs). Democratic Brazil Divided. Pittsburgh: University of Pittsburgh Press, 2017.

TAYLOR, Matthew M. Judging Policy: Courts and Policy Reform in Democratic Brazil. Stanford: Stanford University Press, 2008.

TAYLOR, Matthew M. Veto and Voice in the Courts: Policy Implications of Institutional Design in the Brazilian Judiciary. Comparative Politics, v. 38, n. 3, p. 337-355, 2006. http://doi.org/10.2307/20434001

TAYLOR, Matthew M.; DA ROS, Luciano. Os Partidos Dentro e Fora do Poder: A Judicialização como Resultado Contingente da Estratégia Política. Dados, v. 51, n. 4, p. 825-864, 2008. http://dx.doi.org/10.1590/S001152582008000400002

VASCONCELLOS, Frederico. Lobby dos Juízes está instalado no CNJ. Folha de S.Paulo, 2015. Disponível em: $<$ http://blogdofred.blogfolha.uol.com.br/2015/04/06/lobby-de-juizes-esta-instalado-no-cnj/>. Acesso em: 20 mar. 2016.

VAZ, Caroline. Funçôes da Responsabilidade Civil: da reparação à puniçấo e dissuasão - os punitive damages no direito comparado e brasileiro. Porto Alegre: Livraria do Advogado, 2009.

VIEIRA, Fabiola S. Evoluçào do Gasto com Medicamentos do Sistema Único de Saúde no Período de 2010 a 2016. Texto para Discussão 2356. Brasília: IPEA, 2018.

VIEIRA, Oscar Vilhena. Que reforma? Estudos Avançados, v. 18, n. 51, p. 195-207, 2004.

WANG, Daniel et al. Os impactos da judicialização da saúde no município de São Paulo: gasto público e organização federativa. Revista de Administraçáo Pública, v. 48, n. 5, p. 1191-1206, 2014. http://dx.doi.org/10.1590/003476121666

WILSON, B.; CORDERO, J. C. R. Legal Opportunity Structures and Social Movements: The Effects of Institutional Change on Costa Rican Politics. Comparative Political Studies, v. 39, n. 3, p. 325-351, 2006. https://doi. org/10.1177\%2F0010414005281934 


\section{Resumo}

Juizes eficientes, judiciário ineficiente no Brasil pós-1988

O artigo realiza uma análise descritiva ampla das continuidades e mudanças do poder judiciário ao longo das últimas três décadas no Brasil, tendo em vista especialmente a sua eficiência e eficácia no cumprimento de sua missão institucional, ou seja, a resolução pacífica de conflitos por meio da interpretação obrigatória da legislaçáo. Valendo-se de revisão de literatura e de dados tanto primários como secundários, o artigo salienta, por um lado, a existência de um aparente descompasso entre magistrados de alta produtividade decisória e, por outro, um poder judiciário de baixa resolutividade no Brasil. Esse cenário, por sua vez, origina-se de um sistema judicial marcado por imensa redundância decisória, a qual foi objeto de reforma apenas ocasionalmente ao longo do período estudado, em que pese o elevado volume de reformas realizadas ao longo das últimas décadas.

Palavras-chave: Poder judiciário; Brasil; Eficiência; Reforma do judiciário; Supremo Tribunal Federal.

\section{Abstract}

Efficient judges, ineffcient judiciary branch in post-1988 Brazil

The article performs a broad descriptive analysis of the continuities and changes of the Judiciary Branch over the last three decades in Brazil, paying special attention to its efficiency and effectiveness in the institutional mission fulfilment: the peaceful resolution of conflicts through an authoritative interpretation of the law. The article stresses, on one hand, the existence of an apparent mismatch between judges of high decision-making productivity, and, on the other, a Judiciary Branch of low resolution in Brazil. This scenario, in turn, originates from a judicial system marked by immense decision-making redundancy, which was reformed only occasionally over the studied period, despite the high volume of judicial reforms carried out over the last decades.

Keywords: Judiciary branch; Brazil; Efficiency; Judicial reform; Supreme Court.

\section{Résumé}

\section{Des juges efficaces et le pouvoir judiciaire inefficace au Bresil apres 1988}

Cet article fait une analyse descriptive générale des continuités et des changements du système judiciaire au cours des trois dernières décennies au Brésil, en mettant un accent particulière sur l'efficacité et l'efficience pour la réalisation de sa mission institutionnelle : la résolution pacifique des conflits par interprétation de la loi. On souligne l'existence d'un déséquilibre apparent entre les juges de haute productivité décisionnelle et le pouvoir judiciaire à faible résolution au Brésil. L'origine de ce scénarioest un système judiciaire caractérisé par un énorme licenciement décisionnel, qui n’a été réformé que de temps en temps au cours de la période étudiée, malgré le nombre élevé de réformes judiciaires menées au cours des dernières décennies.

Mots clés: Judiciaire; Brésil; Efficacité; Réforme judiciaire; Court Suprème. 